\title{
Coupling a settlement growth model with an agro- economic land allocation model for securing ecosystem services provision
}

\author{
Thomas Drobnik ${ }^{*}$, Robert Huber ${ }^{b}$, Adrienne Grêt-Regameya \\ a Planning of Landscape and Urban Systems PLUS, Swiss Federal Institute of Technology (ETH), Stefano \\ Franscini-Platz 5, 8093 Zurich, Switzerland \\ b Swiss Federal Institute for Forest, Snow and Landscape Research (WSL), 8903 Birmensdorf, Switzerland \\ *Corresponding author
}

\author{
Keywords: \\ Ecosystem services \\ Spatial planning \\ Mathematical programming model \\ Cellular automata \\ Settlement expansion
}

Journal of Environmental Planning and Management

(DOI: 10.1080/09640568.2016.1197828)

This document is the accepted manuscript version of the following article:

Drobnik, T., Huber, R., \& Grêt-Regamey, A. (2017). Coupling a settlement growth mode1 with an agro-economic land allocation model for securing ecosystem services provision. Journal of Environmental Planning and Management, 60(7), 1127-1152. https://doi .org/10.1080/09640568.2016.1197828 


\section{Abstract}

Mountain landscapes are undergoing rapid land-use changes. Settlement expansion, the intensification of agricultural land-use practices, and farmland abandonment result in a decline of natural and semi-natural habitats and the related ecosystem services (ES). In this context, spatial planning has emerged as a key instrument for the management of ES provision. To better understand trade-offs and interactions between settlement growth and ES provision in a spatially explicit manner, we present a new modelling framework coupling an agent-based, agro-economic optimization model and a cellular-automata-based settlement growth model. The framework is applied in an inner-alpine valley in the Valais, Switzerland, which experienced rapid settlement growth in recent years. Results demonstrate how the model framework allows to support local planning processes. Particularly cooperation among municipalities and an explicit consideration of ES can inform spatially explicit ES trade-off decisions under increasing demand for land. We conclude that better informed spatial planning processes support ES provision. 


\section{Introduction}

Mountain landscapes are the result of centuries of natural and anthropogenic land-use changes (Orland 2004; Bürgi et al. 2009). They provide important ecosystem services (ES), such as food production, drinking water, habitats for animals and plants, as well as cultural services to people living in and outside these areas (GrêtRegamey, Brunner, and Kienast 2012; Huber, Rigling, et al. 2013). Climate and socio-economic changes, however, increasingly threaten a sustainable provision of these services (Fuhrer, Smith, and Gobiet 2014; Beniston 2003; Marini, Klimek, and Battisti 2011; Messerli, Scheurer, and Veit 2011a; Nogués-Bravo et al. 2007).

The challenge to manage long-term provision of ES in mountain landscapes is characterized by a dual development. On the one hand, growing urbanized areas (Perlik, Messerli, and Batzing 2001; Bätzing, Perlik, and Dekleva 1996; Dematteis 2009; Perlik and Messerli 2004; Vaz and Matos 2014) and increasing land-use intensities in agriculture have a negative effect on ES on the valley floors and agronomically productive sites (Marini et al. 2009; Flury, Huber, and Tasser 2013b; Marini, Klimek, and Battisti 2011; Monteiro et al. 2011; Zimmermann et al. 2010). On the other hand, migratory processes (Messerli, Scheurer, and Veit 2011b) and the declining importance of traditional agriculture that originally shaped the landscape (Flury, Huber, and Tasser 2013a; MacDonald et al. 2000; Cocca et al. 2012) lead to a loss of ES provision in more marginal areas. At the same time, rising temperatures due to climate change prolong the vegetation period in temperature limited areas, supporting shrub and forest encroachment which in turn leads to a landscape change (Monteiro et al. 2011; Zimmermann et al. 2010). Thus, it is the interaction of various land-use changes that shapes the landscapes of mountain regions - and also influences the bundles of ES mountainous areas can provide (Antrop 2005; Bürgi et al. 2014; Dupras and Alam 2014).

In this context of spatially explicit interactions of land-use changes, spatial planning emerges as a key management option in ES provision (Huber, Rigling, et al. 2013; de Groot et al. 2010; Geneletti 2011; Koschke et al. 2012; Bryan et al. 2010; Eigenbrod et al. 2011). Spatial planning is of specific importance with respect to settlement expansion since market returns on urban land tend to be higher than returns for other land even under the explicit consideration of ES (Nelson et al. 2009). In order to understand how ES provision can be fostered under increasing pressure from land-use change in general and settlement expansion in particular, a comprehensive understanding of the impact of spatial planning instruments on ES trade-offs over scales and their consequences for the agricultural sector is needed (Zank et al. 2016).

There exists a wide range of research addressing decreasing ES provision in European Alpine regions (Briner, Elkin, and Huber 2013b; Gibon et al. 2010; Price et al. 2015; Lundström et al. 2007; Grêt-Regamey et al. 2008; Briner, Huber, et al. 2012; Huber, Rigling, et al. 2013; Grêt-Regamey, Walz, and Bebi 2008; Grêt-Regamey and Kytzia 2007; Kirchner et al. 2015; Schirpke et al. 2012; Schröter et al. 2005). These studies provide valuable insights into drivers of change, the impact of socio-economic and climatic scenarios, as well as management and policy options that counteract the future loss of ES provision in mountain areas. However, they either focus on the agricultural or forest sector, are applied on a very high aggregation level, or do not explicitly consider management or policy options that could support the provision of ES in the future including the possibility of considering stakeholder preferences. Thus, the integration of scientifically based information on spatially explicit consequences of settlement growth and spatial planning options on agricultural production decisions, considering farmer's preferences and characteristics across different scales (field, farm, landscape) is still an important research challenge.

The objective of our study is to link settlement growth and agro-economic land allocation with the provision of ES in a comprehensive modelling framework to quantify the effect of spatial planning instruments on bundles of ES across different scales in a mountain region. The framework quantifies the impact of these instruments on different ES, i.e., food production, water supply, habitat provision, and different cultural services such as recreation and aesthetics, in a spatially explicit manner. The framework explicitly takes into account preferences and attitudes of different farmers in their decision making, and provides the possibility to include stakeholders in valuing and prioritizing ES, thus supporting local spatial planning processes.

To achieve this goal, we combine an agent-based, spatially explicit, agro-economic Land-Use-Land-Cover model and a cellular automata settlement growth model to assess land-use and related ES changes with various spatial planning instruments. 
The advantage of an agent-based model is that it allows to take into account different farmers' characteristics in their decision making, which play an important role in mountain farming systems. In addition, it allows to dynamically calculate agricultural land-use changes and ES provision across different scales. Thus, agricultural and forest land-use changes can be directly linked to settlement growth and spatial planning instruments. The model has been tested extensively and applied in various ES studies (Briner, Elkin, et al. 2012; Brändle et al. 2014; Briner, Elkin, and Huber 2013a; Huber et al. 2014; Briner et al. 2013; Brunner, Huber, and Grêt-Regamey 2016). The cellular automata model allocates new settlement parcels considering location factors and ES provision capacity. Based on a multiple criteria decision analysis MCDA (Malczewski 1999, 2006), values and weights for ES can be defined in stakeholder meetings and workshops.

Thus, this framework adds to existing research the possibility to comprehensively assess the potential of spatial planning instruments on agricultural production and resulting trade-offs in ES provision. Our case study region is suitable to evaluate the effects of spatial planning policies since it explicitly experiences the dual development of rapidly growing settlement areas and an increase in land-use intensities - in the main municipality of Visp and the tourist dominated Saas Fee - as well as a decline of traditional agriculture in more remote areas. In addition, a recent survey showed that people in the valley consider settlement expansion the most important driver of landscape changes and ES loss (Brunner, Huber, and Grêt-Regamey 2016). Furthermore, the latest revision of Swiss Spatial Planning Law forces municipalities to coordinate their planning efforts. Thus, there is a need for new and innovative tools that support local planning processes.

\section{Case study region}

The case study region lies within the Canton of Valais in the southwest of Switzerland. Besides the name-giving city of Visp and its corresponding (main) valley, it also encompasses the valleys of Saas and Baltschieder. Twelve municipalities are included within the boundaries of the case study region, all of them belonging to the district of Visp: Baltschieder, Eisten, Saas-Balen, Saas-Fee, Saas-Grund, Saas-Almagell, Visp, Visperterminen, and Zeneggen. The one exception is the village of Eggerberg, which belongs to the neighboring district of Brig. The entire case study area covers an area of $348.8 \mathrm{~km} 2$ and is home to 16021 residents (as of 2013) (FSO 2015b) among which are 161 farmers, and their family members (Brändle et al. 2014). The secondary sector is primarily located in the valley bottom around Visp with more than $50 \%$ of employees working for the century-old Lonza AG (Visp 2015). In the rural areas, the primary sector and tourism - especially winter tourism - are the most important sources of income (Brand et al. 2013). Farming activities focus on grassland-based livestock production and sheep farming, with crop farming playing only an insignificant role (FOA 2013). Primary and best accessible farming land is also located at the valley bottom around Visp (VSGIS 2015; FSO 2015b). However, like many other inner-alpine valleys, the Visp area suffers from decline in the primary sector with an annual decrease of farms of 2.8\%. At the same time, forest area increased by 252 ha between 1997 and 2009 (Brändle et al. 2014). Settlement also shows an increase in both, area (plus $87 \mathrm{ha}$ ) and average spatial demand per person (plus 18\% on average) (FSO 2015b). Finally, the case study area is prone to climate change, as the dry continental climate of an inner alpine mountain valley is expected to suffer increasingly dry summers, reduced snow reliability in winter and increased likelihood of natural hazards (Brand et al. 2013).

\section{Methods}

\subsection{Framework}

Our framework is a multi-scale, recursive-dynamic modelling framework designed to assess land-use and associated ES provision changes under various policies and spatial planning instruments. The framework links two models (Figure 1): a recursive-dynamic agent-based land-use model (the Alpine Land-Use Allocation Model ALUAM (Briner, Elkin, et al. 2012)) and an automated settlement transition model (the Dynamic Settlement Allocation model DSA). Both models are spatially explicit with a resolution of $100 \mathrm{~m}$ x $100 \mathrm{~m}$ per raster cell. 
Based on a land-use map as well as agro-economic input data, ALUAM simulates land-use changes and ES provision in agriculture and forestry under different scenarios by maximizing the aggregated income of farmers and foresters in the case study region. The resulting land-use map is subsequently transferred to the settlement allocation model DSA.

DSA then calculates the demand for new settlement areas in the case study region, based on average spatial demand per person and projected population development, and allocates the required amount of settlement cells based on location factors (LF) and ES. In a recursive-dynamic manner, the resulting land-use map is transferred back into ALUAM as input. By modifying the input parameters of the framework, land-use changes and agricultural activities can thus be simulated under various agricultural policy schemes, market prices, population growth scenarios, and spatial planning instruments. For use in participatory processes, our framework supports the inclusion of stakeholder preferences by adding weights to both, LF and ES. The modelling framework is available upon request.

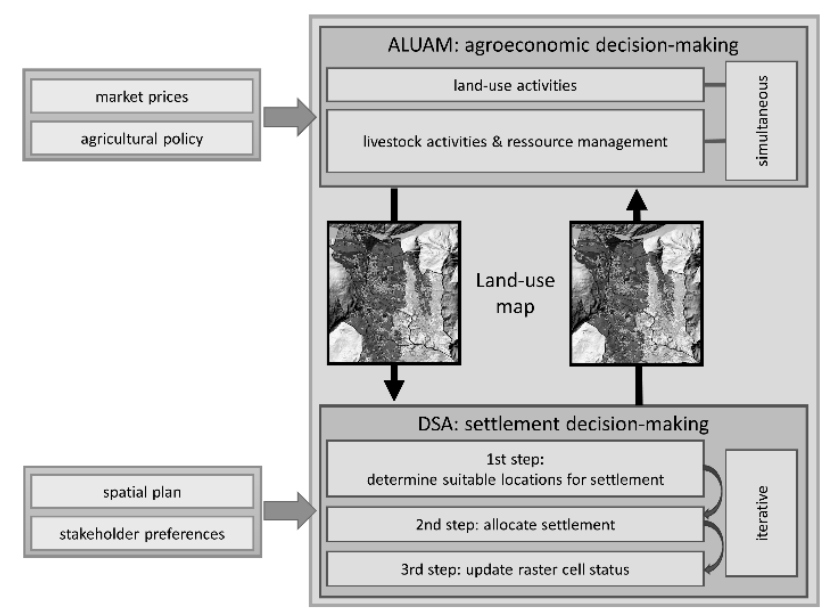

Figure 1: Framework overview. ALUAM maximizes agricultural income, which affects both, land-use activities of agricultural agents as well as how they manage their livestock and their resources. A raster-based land-use map is generated and transferred to $D S A$. Subsequently, DSA iteratively allocates new settlement cells and transfers the resulting raster map back. to ALUAM.

\subsection{Alpine Land-Use Allocation Model ALUAM}

ALUAM is a spatially explicit, normative mathematical programming model using a recursive-dynamic agentbased approach. The purpose of the model is to simulate agricultural and forest land-use changes as well as corresponding spatially explicit changes in ES provision under different climate and socio-economic scenarios. The model is defined by interconnected human and environmental/agronomic subsystems, described in detail in (Brändle et al. 2014; Briner, Elkin, et al. 2012). The human subsystem is defined by farm agents which decide on agricultural and forest activities. Agents allocate their resources based on a constraint income maximization approach. Each agent represents a group of farms, differing from other agents in variables like finances (opportunity costs, desired minimum income), farming objectives and preferences (fattening vs dairy farming, intensive vs extensive management), household composition (age, family members) and resource availability (land, labor). The clustering of the farms into agents as well as the agents' characteristics were derived from agricultural census data, a farm survey, and interviews using a principal component analysis (PCA), yielding five different types of farmers. Production-oriented farmers (type 1) rely on farming as primary source of income, with focus on high yields, and most, or all of their available labor devoted to farming. Type 2, the ecological farmers - also named landscaped stewards - value the provision of ecological services and maintenance of biodiversity higher than yields or monetary pay-off, and often prefer extensive land-uses. The other three types are made up from leisure-oriented farmers, with main income earned off-farm. Type 3 is oriented towards breeding, and often has a competitive mindset. Type 4 runs small-scale part-time farms to maintain local 
traditions and traditional landscapes, and type 5 farms for personal enjoyment. For more detail on the agent types, please refer to Appendix A.6, Table A. 2, and Table A. 3.

The environmental/agronomic subsystem is characterized by the agricultural production environment in the case study area and topographical factors. Agronomic variables include plant nutrient requirements (nitrogen, phosphor), manure production, and production coefficients, such as fodder intake, growth, birth, deaths of animals, and labor requirements. The model includes four categories of livestock (dairy, fattening, suckler cow, lamb) with several production intensities and stable systems. Data for the environmental/agronomic system is based on Swiss average data. Production-related variables are aggregated at the agent level and represent values over one year. Influence of the natural conditions on crop yield and forest yield is externally pre-processed in a spatially explicit manner using crop and forest models.

To link livestock and land-use activities, the environmental/agronomic system uses material balances to integrate environmental variables in the agents' decision making processes, allowing spatially explicit definition of land-use intensities. Finally, crop rotation requirements and labor balance are used as additional constraints to link the human system with the environmental/agronomic system.

Farm structural change and agent interactions are simulated on the parcel level using a land-market model. Raster cells enter the land-market if one of three conditions is met: 1) an agent does not reach its minimum income threshold and the farm is abandoned, 2) a farmer retires without successor and thus all his land enters the land market, or 3) a parcel consists of more than $50 \%$ of uncultivated land. Based on a random process, the parcel is assigned to another agent who takes over the parcels if he can increase his profit.

As an indicator for food production, the model calculates food units as a standardized output parameter for grassland and cropland productivity, dairy farming, and animal fattening where one food unit equals the nutrition of 100 kilograms of wheat.

For scenario modelling, a set of downscaled IPCC scenarios is available, accounting for changes in climate and providing the framework for linked economic story lines. As previous model runs have shown, the scenarios result in a decreased production, a shift from cropland to grassland, and an increase in forested areas. Generally, the model predicts worsened economic conditions to have a stronger impact on the agriculture in the case study area than worsened climatic conditions.

\subsection{Dynamic settlement allocation model DSA}

DSA is an automated settlement transition model using a "suitability score", i.e., a quantitative scoring system to identify raster cells with the highest suitability for settlement conversion. The purpose of the model is to simulate settlement development under different spatial planning measures considering spatially explicit location factors and ES potentials.

Resolution of the raster map is $100 \mathrm{~m} \times 100 \mathrm{~m}$ per cell, matching the ALUAM grid in both alignment and resolution. The model includes (1) a dynamic calculation of the suitability score per iteration and (2) cellularautomata-based transition rules.

The calculation of the suitability scores is based on a MCDA with a set of criteria, i.e., LF and ES. Seven criteria are related to the provision of ES and eight criteria are related to the quality of LF. Table 1 and Table 2 give a detailed overview of all criteria used in the DSA model, differentiated into ES, exclusions (Table 1), and LF (Table 2). They are based on data from federal or cantonal administration. "Aesthetics" and "water supply (recharge)" are two exceptions: "Aesthetics" data are based on a visibility map developed by HSR Hochschule für Technik Rapperswil (Lienhard and Binna 2013). The dataset for "water supply (recharge)" originates from the ground water process model PREVAH (Viviroli et al. 2009).

To integrate the different dimensions, the criteria were normalized using criteria-specific value functions assembled via Delphi survey, with either a direct-rating-method for discrete criteria or the mid-value-method for continuous criteria. Per criteria, a board of experts in the respective field, consisting of scientists and practitioners, has been selected and asked to anonymously rate the criteria over two to three iterations until reaching consensus. In addition to ES and LF criteria maps, DSA needs census data, data on projected population growth, on area covered by settlement, on municipal boundaries, and on adjacency of raster cells 
(Table 3). All criteria have been prepared using esri ArcGIS 10.1. The selection of a total of 15 criteria was based on literature reviews and on open interviews with a group of experts.

The overall goal of settlement expansion in DSA is to minimize the negative impact on ES provision while maximizing the value of location factors. Consequently, ES criteria are cost criteria (lower is better), whereas LF criteria are benefit criteria (higher is better). 
Table 1: List of ES criteria used in our framework, classified according to MEA (2005).

\begin{tabular}{|c|c|c|c|c|}
\hline Type & Criteria & $\begin{array}{l}\text { Category } \\
\text { (MEA 2005) }\end{array}$ & Indicator used & Data source \\
\hline \multirow{7}{*}{ 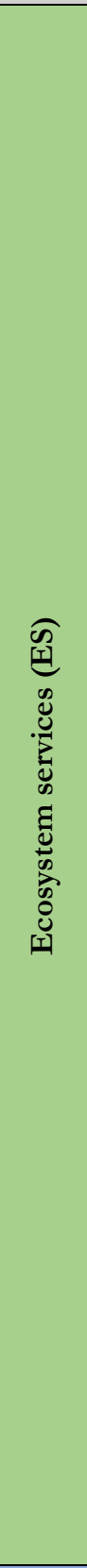 } & $\begin{array}{l}\text { Food } \\
\text { production }\end{array}$ & Provisioning & $\begin{array}{l}\text { Swiss suitability map for agricultural production with } \\
\text { five classes, where: } 1=\text { worst suitability, low yields, } \\
\text { undemanding crops only; } 5 \text { = best suitability, high } \\
\text { yields, perfect for all crops. Suitability classes were } \\
\text { normalized for MCDA using Delphi survey. }\end{array}$ & $\begin{array}{l}\text { Digital soil } \\
\text { suitability map } \\
\text { (FSO 2000) }\end{array}$ \\
\hline & $\begin{array}{l}\text { Water supply } \\
\text { (recharge) }\end{array}$ & Regulating & $\begin{array}{l}\text { Rate of groundwater recharge (regulation and filtering } \\
\text { in the soil) in liters/hectare. Average monthly } \\
\text { recharge rate, based on water systems (discharge, } \\
\text { barriers, hydropower), precipitation, soil type (field } \\
\text { capacity, soil depth, water permeability, groundwater, } \\
\text { exposition), geology, land-use, and temperature. } \\
\text { Recharge rate was normalized for MCDA using } \\
\text { Delphi survey. }\end{array}$ & $\begin{array}{l}\text { Estimated monthly } \\
\text { recharge values } \\
1981 \text { - 2000 based } \\
\text { on model PREVAH } \\
\text { (Zappa 2002; } \\
\text { Viviroli et al. 2009) }\end{array}$ \\
\hline & $\begin{array}{l}\text { Water supply } \\
\text { (protection) }\end{array}$ & Regulating & $\begin{array}{l}\text { Groundwater protection categories in drinking water } \\
\text { catchments. Five categories: three categories directly } \\
\text { related to catchment protection, consisting of a core } \\
\text { (S1) and two buffer levels (S2, S3); one category (Au) } \\
\text { designating areas with general protection of water } \\
\text { bodies, and one category (OS) marking non-protected } \\
\text { areas. Categories were normalized for MCDA using } \\
\text { Delphi survey. }\end{array}$ & $\begin{array}{l}\text { Groundwater } \\
\text { protection areas } \\
\text { (FOEN 2011a) }\end{array}$ \\
\hline & $\begin{array}{l}\text { Habitat } \\
\text { function }\end{array}$ & Supporting & $\begin{array}{l}\text { Location of forest habitats, wetland habitats, aquatic } \\
\text { habitats, dry meadows, extensive meadows, and } \\
\text { known wildlife corridors. One out of two values } \\
\text { possible per raster pixel: either containing one of the } \\
\text { above habitats (1) or not ( } 0 \text { ). No Delphi survey } \\
\text { performed, information has been used for MCDA } \\
\text { without modification. }\end{array}$ & $\begin{array}{l}\text { Protected sites and } \\
\text { wildlife corridor } \\
\text { maps (FOEN } \\
\text { 2011b, 2013) }\end{array}$ \\
\hline & $\begin{array}{l}\text { Recreation } \\
\text { (close-by) }\end{array}$ & Cultural & $\begin{array}{l}\text { Demand for close-by recreation per raster cell. For } \\
\text { calculation of the demand, a minimum of } 8 \mathrm{sqm} \\
\text { unobstructed area within a linear distance of } 400 \mathrm{~m} \text { per } \\
\text { resident was assumed (Zurich 2006). For } \\
\text { normalization, official classification of the city of } \\
\text { Zurich has been used (Zurich 2006). }\end{array}$ & $\begin{array}{l}\text { Land Use Statistics } \\
\text { (FSO 2009); } \\
\text { Municipal } \\
\text { population } \\
\text { development 1981 - } \\
2010 \text { (FSO 2012) } \\
\end{array}$ \\
\hline & Aesthetics & Cultural & $\begin{array}{l}\text { Amount of raster pixels that can be seen from a given } \\
\text { raster pixel within a radius of } 5 \mathrm{~km} \text {. Allows } \\
\text { identification of locations with great vistas. } \\
\text { Continuous values, normalized for MCDA using } \\
\text { linear transformation. }\end{array}$ & $\begin{array}{l}\text { Visibility Map } \\
\text { CHSR (Lienhard } \\
\text { and Binna 2013) }\end{array}$ \\
\hline & $\begin{array}{l}\text { Recreation } \\
\text { (quietness) }\end{array}$ & Cultural & $\begin{array}{l}\text { Noise level in } \mathrm{dB} \text { per raster pixel, calculated based on } \\
\text { noise emitted by road, railway, and air traffic. } \\
\text { Normalized for MCDA using Delphi survey. }\end{array}$ & \begin{tabular}{|l} 
sonBASE noise \\
database (FOEN \\
2009)
\end{tabular} \\
\hline \multirow{2}{*}{ 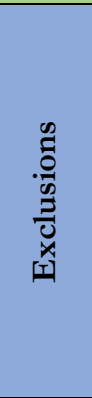 } & $\begin{array}{l}\text { Crop } \\
\text { rotation } \\
\text { areas }\end{array}$ & Provisioning & $\begin{array}{l}\text { In Switzerland, highly fertile agricultural areas (named } \\
\text { "crop rotation areas") are specifically designated in } \\
\text { structural plans and they are not available for } \\
\text { constructions of any kind under normal circumstances } \\
\text { (Swiss Spatial Law, Art. 30). Consequently, all crop } \\
\text { rotation areas are excluded. }\end{array}$ & $\begin{array}{l}\text { Inventory of } \\
\text { Agricultural } \\
\text { Production } \\
\text { Potential; property } \\
\text { of the cantons }\end{array}$ \\
\hline & Forest area & $\begin{array}{l}\text { Provisioning } \\
\text { Regulating }\end{array}$ & $\begin{array}{l}\text { In Switzerland, forests are protected by law, and } \\
\text { construction in forests is not allowed under normal } \\
\text { circumstances (Swiss Forest Law, Art. 5, 11, \& 12). } \\
\text { Consequently, all forest areas are excluded. }\end{array}$ & $\begin{array}{l}\text { Land Use Statistics } \\
\text { (FSO 2009) }\end{array}$ \\
\hline
\end{tabular}


Table 2: List of LF criteria used in our framework.

\begin{tabular}{|c|c|c|c|}
\hline Type & Criteria & Indicator used & Data source \\
\hline \multirow{8}{*}{ 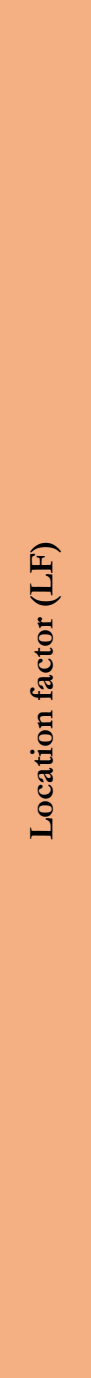 } & $\begin{array}{l}\text { Access by } \\
\text { individual } \\
\text { transport }\end{array}$ & $\begin{array}{l}\text { Distance to the next highway exit per pixel in three steps using } \\
\text { esri ArcGIS 10.1: first calculating distance to highway exit for } \\
\text { each road pixel using "path distance", then calculating the } \\
\text { distance of non-road pixels to closest road pixel using "euclidian } \\
\text { allocation". Finally, layers are added up. Normalized for MCDA } \\
\text { using Delphi survey. }\end{array}$ & $\begin{array}{l}\text { Topographic Land } \\
\text { Model (TLM) } \\
\text { Swisstopo } \\
\text { (Swisstopo 2013) }\end{array}$ \\
\hline & $\begin{array}{l}\text { Access by } \\
\text { public } \\
\text { transport }\end{array}$ & $\begin{array}{l}\text { Official map of public transport quality. Travel time with public } \\
\text { transport to regional centers considering train, bus, tram, cable } \\
\text { car, and boat infrastructures. Categorized into seven levels of } \\
\text { public transportation quality, where " } 1 \text { " is highest quality and "7" } \\
\text { is lowest quality. Normalized for MCDA using Delphi survey. }\end{array}$ & $\begin{array}{l}\text { Infoplan } \quad \text { (years } \\
2012-2013) \\
(\text { FSOD 2012) }\end{array}$ \\
\hline & $\begin{array}{l}\text { Distance to } \\
\text { existing } \\
\text { settlement }\end{array}$ & $\begin{array}{l}\text { Distance to existing settlement per pixel, calculated using "path } \\
\text { distance" in esri ArcGIS. Lone houses outside of coherent } \\
\text { settlements have not been considered "existing settlement". } \\
\text { Normalized for MCDA using Delphi survey. }\end{array}$ & $\begin{array}{l}\text { TLM Swisstopo } \\
\text { (Swisstopo 2013) }\end{array}$ \\
\hline & $\begin{array}{l}\text { Density of } \\
\text { utility } \\
\text { services }\end{array}$ & $\begin{array}{l}\text { Classification of businesses offering utility services into two } \\
\text { classes: "daily needs" (weight: } 3 \mathrm{x} \text { ) and "periodical needs" (weight: } \\
\text { 1x). Calculation of utility service density within } 1000 \mathrm{~m} \text { of a raster } \\
\text { pixel using "point density" in esri ArcGIS } 10.1 \text {. Normalization for } \\
\text { MCDA using Delphi survey. }\end{array}$ & $\begin{array}{l}\text { Business Census } \\
\text { (FSO 2008) }\end{array}$ \\
\hline & $\begin{array}{l}\text { Quiet } \\
\text { residential } \\
\text { areas }\end{array}$ & $\begin{array}{l}\text { Noise level in } \mathrm{dB} \text { per raster pixel, calculated based on noise } \\
\text { emitted by road, railway, and air traffic. Normalized for MCDA } \\
\text { using Delphi survey. }\end{array}$ & $\begin{array}{lr}\text { sonBASE } & \text { noise } \\
\text { database } & \text { (FOEN } \\
2009) & \end{array}$ \\
\hline & Exposition & $\begin{array}{l}\text { Exposition of slopes, calculated in esri ArcGIS } 10.1 \text { using "slope", } \\
\text { then categorized into four exposition categories: "S" }\left(135^{\circ}-\right. \\
\left.225^{\circ}\right) \text {, "SE/SW" }\left(90^{\circ}-135^{\circ} ; 225^{\circ}-270^{\circ}\right) \text {, "NE/NW" }\left(45^{\circ}-90^{\circ} \text {; }\right. \\
\left.270^{\circ}-315^{\circ}\right) \text {, "N" }\left(315^{\circ}-45^{\circ}\right) \text {. Normalized for MCDA using } \\
\text { Delphi survey. }\end{array}$ & $\begin{array}{l}\text { Digital Elevation } \\
\text { Model (DEM) } \\
\text { Swisstopo } \\
\text { (Swisstopo 2007) }\end{array}$ \\
\hline & Slope & $\begin{array}{l}\text { Average slope per raster pixel (in percent) extracted from the } \\
\text { DEM using "slope" in esri ArcGIS. Normalization for MCDA } \\
\text { using Delphi survey. }\end{array}$ & $\begin{array}{l}\text { DEM Swisstopo } \\
\text { (Swisstopo 2007) }\end{array}$ \\
\hline & $\begin{array}{l}\text { Natural } \\
\text { hazard risk }\end{array}$ & $\begin{array}{l}\text { Risk of natural hazards in six risk levels per raster pixel: "1" }= \\
\text { substantial risk; " } 2 \text { " = medium risk; " } 3 "=\text { low risk; "4" = } \\
\text { marginal risk; " } 5 "=\text { hazard warning; "6" = no risk. Normalized } \\
\text { for MCDA using Delphi survey. }\end{array}$ & $\begin{array}{l}\text { Natural hazard } \\
\text { maps; property of } \\
\text { the cantons }\end{array}$ \\
\hline
\end{tabular}

Table 3: Data required to run the DSA model in addition to ES and LF criteria maps.

\begin{tabular}{|l|l|l|l|}
\hline \multicolumn{1}{|c|}{ Required } & \multicolumn{1}{|c|}{ Description } & \multicolumn{1}{c|}{ Type } & \multicolumn{1}{c|}{ Data source } \\
\hline $\begin{array}{l}\text { Municipal } \\
\text { census data }\end{array}$ & $\begin{array}{l}\text { Population data for each municipality within } \\
\text { the study area }\end{array}$ & $\begin{array}{l}\text { Table; } \\
\text { aggregated at } \\
\text { municipal level }\end{array}$ & $\begin{array}{l}\text { Municipal population } \\
\text { development 1981 - 2010 } \\
\text { (FSO 2012) }\end{array}$ \\
\hline $\begin{array}{l}\text { Municipal } \\
\text { boundaries }\end{array}$ & $\begin{array}{l}\text { Boundaries of the municipal responsibility } \\
\text { jurisdiction?) }\end{array}$ & $\begin{array}{l}\text { Vector-based } \\
\text { shape file }\end{array}$ & $\begin{array}{l}\text { Municipal boundaries } \\
\text { (Swisstopo 2015) }\end{array}$ \\
\hline $\begin{array}{l}\text { Population } \\
\text { growth }\end{array}$ & $\begin{array}{l}\text { Estimated population growth based on three } \\
\text { official scenarios [\%/yr]: "low", "medium", } \\
\text { and "high". The scenario "medium" is also } \\
\text { the official reference scenario. }\end{array}$ & $\begin{array}{l}\text { Table; } \\
\text { aggregated at } \\
\text { cantonal level }\end{array}$ & $\begin{array}{l}\text { Cantonal population } \\
\text { scenarios 2010 - 2035 } \\
\text { (FSO 2011) }\end{array}$ \\
\hline $\begin{array}{l}\text { Settlement area } \\
\text { Settlement }\end{array}$ & $\begin{array}{l}\text { Total area covered by settlement [ha] } \\
\text { raster cells }\end{array}$ & $\begin{array}{l}\text { Raster map, 100 } \\
\text { x 100 m }\end{array}$ & $\begin{array}{l}\text { Land Use Statistics (FSO } \\
\text { 2015a) }\end{array}$ \\
\hline $\begin{array}{l}\text { Raster } \\
\text { adjacency }\end{array}$ & $\begin{array}{l}\text { Which raster cells are adjacent to any given } \\
\text { raster cell }\end{array}$ & $\begin{array}{l}\text { Point-based } \\
\text { xhape file } 100 \text { m; updated } \\
\text { after each year }\end{array}$ & $\begin{array}{l}\text { Based on Land Use } \\
\text { Statistics (FSO 2015a) }\end{array}$ \\
\hline
\end{tabular}


The model runs through a user-defined number of cycles, where each cycle represents a one-year step in time. Within one cycle, settlement allocation is performed over several iterations. For each model cycle, DSA is initialized with the standardized criteria maps linked to weight factors. Total suitability scores per raster cell are calculated and updated after every iteration as described in equation 1. To account for stakeholder preferences or local expert knowledge, each criteria can be weighted individually. In this contribution all criteria were weighted equally and did not change over time.

equation 1: $S_{\text {tot }}=\frac{\sum_{i=1}^{n} E S_{i} * w_{i}}{n}+\frac{\sum_{j=1}^{m} L F_{j} * w_{j}}{m}$;

with: $S_{\text {tot }}=$ total suitability score; $n=$ number of ES criteria;

$m=$ number of LF criteria; $w=$ weight factor

After determining the total suitability score, the model reduces the amount of raster cells available for settlement conversion by removing all raster cells on already built-up areas and areas not adjacent to existing settlements from the solution space. As Swiss laws do not allow the conversion of highly fertile agricultural land and forest areas to settlement areas, these are also excluded (Appendix A.7 provides a detailed description, including Figure A. 3).

For the remaining raster cells, the number that need to be converted to settlement is calculated based on population growth and the average per-capita spatial demand (described in Appendix A.2). For each converted raster cell, DSA runs one iteration. If two or more raster cells have an identical suitability score, the averaged suitability of the neighboring cells are calculated and the competing cells are ranked according to this value. DSA keeps iterating until the target number is reached, with each iteration converting one raster cell from its previous land-use to settlement. In a last step, the land-use map is updated with the new settlement raster cells and agricultural activities restricted to the remaining agricultural area. Additionally, the iterative approach of DSA allows to track impacts of settlement expansion on both, ES provision and agricultural income on a yearly basis, as well as investigating how different spatial planning instruments or stakeholder weights affect the spatial distribution of settlement expansion over time.

A sensitivity analysis of DSA shows that the model reacts sensitively to changes in the required number of neighboring settlement cells, with a clear tendency towards path dependency if four or more neighboring settlement cells are required. Stakeholder preferences (i.e., weights) become important if they are either very pronounced or the required number of neighboring settlement cells is set to two (2) or above. For more information on the sensitivity of DSA, refer to Appendix A.5 (Figure A. 2 and Table A. 1).

ES provision on the sealed areas is considered lost and the raster cells' suitability rating is modified accordingly. For the assessment of the resulting ES trade-offs, original ES provision of sealed areas is stored separately as loss of ES provision. The established value functions are then used again to transform the dimensionless criteria value of each ES into three qualitative categories, "low ES provision", "medium ES provision", and "high ES provision", for trade-off assessment. Their value ranges have been adapted to the case study area using linear transformation. Exceptions are the ES "habitat function" and "recreation (close-by)", for which source data allows only a binary categorization: either provided ("high ES provision") or not provided ("low ES provision"). For each raster cell, a dimensionless ES value (ES-V) is then calculated per category, i.e., every raster cell features its own distribution of ES-V among the three categories. For information on the scarcity of a given ES and its respective quality, an impact ratio was calculated for three different scales (region, cooperation, municipality). The impact ratio indicates the average percentaged decrement per raster cell, and per ES quality, over all raster cells transitioned to settlement.

\subsection{Stakeholders}

The stakeholder process was divided in three phases. First, a group of national experts defined value functions for the different ES and LF criteria in a Delphi survey in order to be able to aggregate the individual criteria in 
a suitability index. Experts for the Delphi survey (Turoff 1975; Powell 2003; Okoli and Pawlowski 2004) were chosen for each criterion individually guided by three selection principles: each expert group should (1) consist of three to five experts, (2) contain experts dedicated to the criterion in question, and (3) contain interdisciplinary experts as well. Experts anonymously rated the criteria over two to three rounds of questionnaires until reaching consensus, the questionnaires of the later stages including anonymized ratings of the previous round. Value functions were built based on decomposed scaling (Beinat 1997).

Secondly, a steering group representing the core stakeholders was set up in the study region. With this group, problem identification and preliminary modeling results were repeatedly discussed (Huber, Bugmann, et al. 2013). The core group was selected using the simplified stakeholder identification process suggested by Reed et al. (2009). Five stakeholders representing the farming and forest sector as well as consultants from spatial planning, regional, and economic development advised on scenario selection and visualization of results. In addition, this core group coordinated the involvement of additional stakeholders in testing the decision support system.

Thirdly, the implementation of the modeling framework in a virtual spatial decision support system was tested with an extended core group including NGOs, administration, and local politicians. For the workshop discussed in this contribution, ten stakeholders reviewed and discussed advantages and possible applications of the decision support platform. Participants covered a broad range of interests, including agriculture, cantonal administration, NGOs, municipal councils, and one member of the cantonal Council (for details, please refer to Appendix A.4).

\subsection{Reference state and spatial planning instruments}

In order to illustrate the model's capabilities, we explored how two different spatial planning instruments affect the provision of ES.

The reference state ("reference") is described by the following main characteristics: On the one hand, settlement growth is based on the official population development scenarios for the Canton of Valais provided by the Swiss Federal Office for Statistics (FSO 2011). We use the "medium" scenario, which is also the official Swiss reference scenario for population development, reflecting a continuation of existing trends (FSO 2015c). The distribution of the population on the surface is based on the average spatial demand per person and year, which was manually calculated - and separately for each municipality within the case study region - by dividing the settlement area derived from Swiss Land Use Statistics (FSO 2015a) by the number of permanent residents (for more information, please refer to Appendix A.2). For simplification, we assume constant spatial demand per person from 2010 to 2035. Furthermore, we do not model shrinking of settlement areas. On the other hand, climate and socio-economic developments, i.e., prices and policies in the agricultural and forest sector are based on the regional downscaled IPCC scenario B1 (Walz et al. 2014). In this scenario, agricultural policy relies on continued direct payments for the provision of ES as well as stable prices for agricultural products and commodities. To illustrate effects of spatial planning instruments, we assume climatic conditions to remain stable.

To investigate the impact of spatial planning instruments on the future potential of the case study region's landscape to provide important ES, we simulate two different planning instruments, i.e., the building zones restrictions and cooperation between municipalities. Both spatial planning instruments are applied with ("ES") and without considering ES ("noES").

\section{Building zones:}

In Switzerland, construction is currently restricted to building zones defined by the municipalities for the next 15 years (Swiss Spatial Planning Law, Art.15/1). In order to explore the ability of currently designated building zones to preserve ES, we simulate settlement expansion by allowing settlement development either only within designated building zones (abbreviated "bz") or on every suitable raster cell that is adjacent to existing settlement (abbreviated "no bz"). 


\section{Cooperation of municipalities:}

According to the recent revision of the Swiss spatial development regulation, municipalities are required to cooperate when defining their building zones (Swiss Spatial Planning Law, Art 15/3). The second spatial planning instrument thus addresses the cooperation among municipalities. To understand the effect of such a cooperation on ES, we make out three cases:

a. Municipalities allocate all settlement expansion completely within their own boundaries (no cooperation; abbreviated: "no coop")

b. Municipalities close to each other cooperate if spatial planning interests overlap (limited cooperation; abbreviated: "It $\boldsymbol{c o o p}$ "; for details, refer to Appendix A.1)

c. All municipalities within the case study region cooperate (regional cooperation; abbreviated: "reg coop")

For each of these five model runs, ES can be considered or not making for a total of ten different combinations. These variations are compared against the reference state.

\section{Results}

\subsection{Consideration of ES alters distribution of settlement area}

Modeling results show that the distribution of new settlement areas until 2035 is highly dependent on the consideration of building zones and ES (Figure 2). The most obvious changes occur around Visp, as this municipality gets most of the new settlement cells ( 71 ha in total), with $48 \%$ of the new settlement cells allocated differently than in the reference state. Other areas have a lower number of totally distributable settlement cells (between 3 ha and 29 ha) but show a higher difference compared to the reference state than the area around Visp. For instance, the area around Eggerberg (Figure 2, box A) presents a very distinctive change in settlement distribution: $75 \%$ (6 ha out of $8 \mathrm{ha}$ ) of the new settlement cells in this municipality are allocated differently when considering ES. The municipalities in the upper valley (not shown) record more than $50 \%$ changes in settlement allocation when considering ES. In contrast, development at the eastern fringes of Visp (Figure 2, box B) shows only minor change compared to the reference state, indicating that in this part of the town criteria for designating building zones and the model's goals of choosing the best suitable areas for new settlement development match. A similar pattern can again be seen in the upper valley for the tourism region of Saas-Fee where demand for vacation homes is high (see Appendix A.3 and Figure A. 1 for details).

\subsection{Changes in ES provision with and without municipal cooperation}

These results suggest that the spatially explicit provision of ES could be improved by allocating settlement areas outside the current distribution of designated building zones. The aggregation of the results on a regional level supports these findings (Figure 3). Allocating settlement cells by ES (no coop, no bz, ES) significantly improves preservation of areas providing medium to high food production and recreation (close-by) in comparison to the reference state. Water supply (recharge), water supply (protection), habitat function, and aesthetics are not or only marginally affected by spatial planning instruments at the aggregated level. Geographically located in the fertile valley floor, many of the raster cells in Visp feature high ES supply, and municipal demand for housing is also high. Consequently, allocating settlement without considering ES and consideration of cooperation might create unintentional trade-offs, in this case loss of areas providing ES such as "food production" and "recreation (close-by)". 


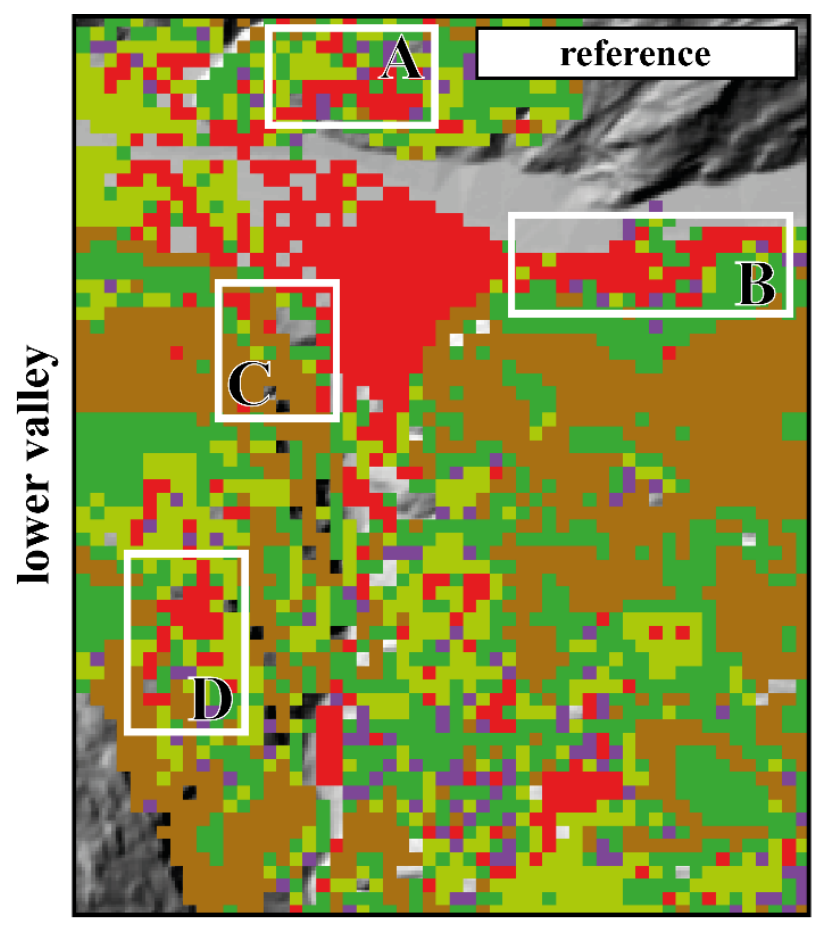

Land use key

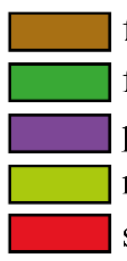

Whinite mumbers: \# of new settlement cells that changed location / total \# of new settlement cells

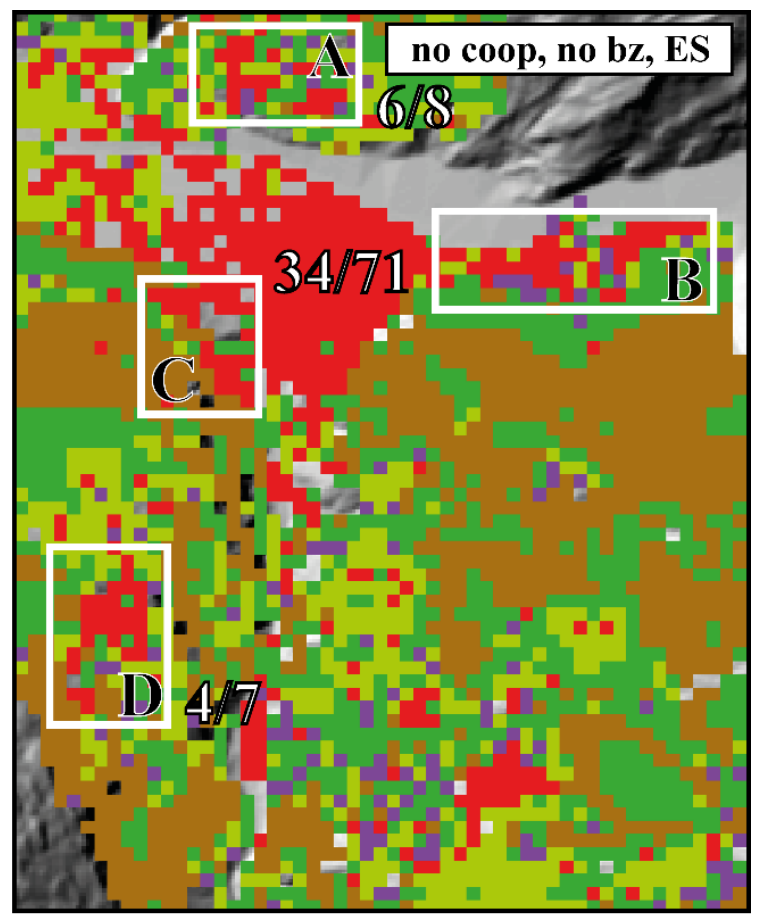

Municipalities

A: Eggerberg

B \& C: Visp

D: Zeneggen

Figure 2: Effect of both, ES consideration and the removal of the building zones on settlement distribution in the lower valley. "no coop" = no cooperation among municipalities; "no br." = building zones are not considered for settlement allocation; "ES" = ES are considered for settlement allocation.

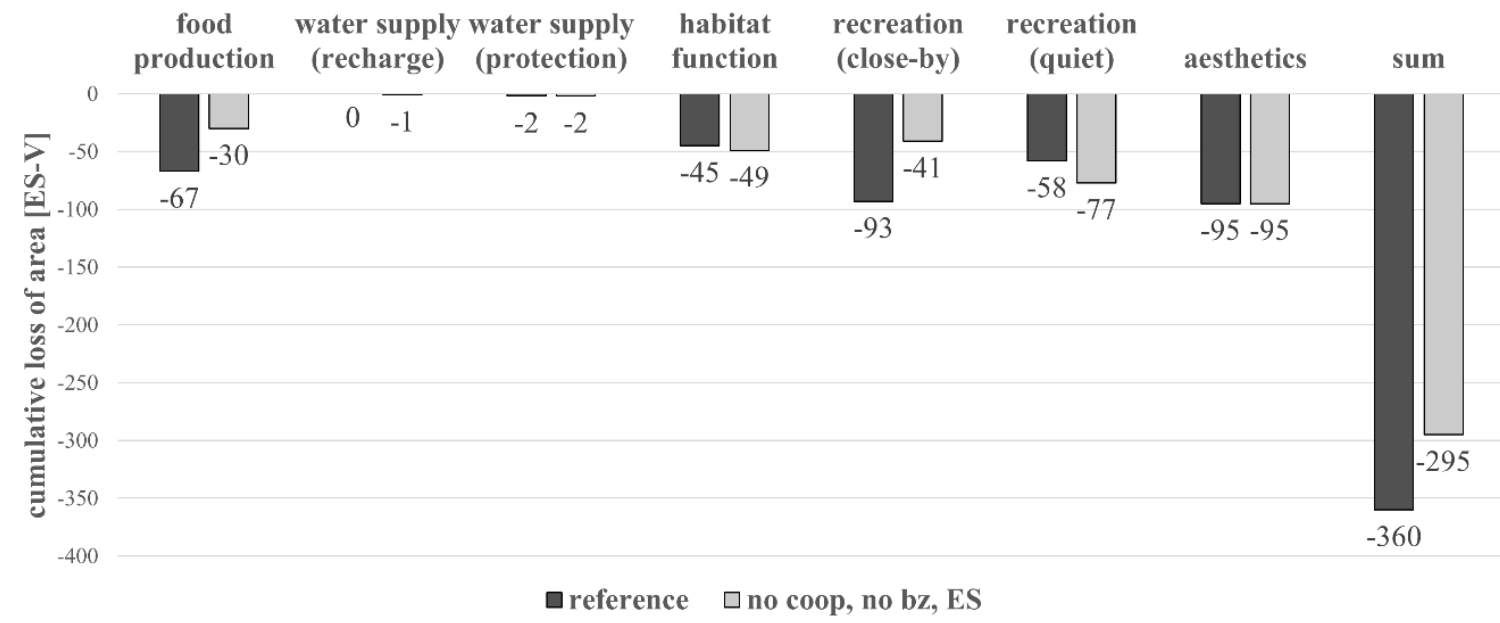

Figure 3: Cumulative loss of medium to high ES quality; aggregated on the regional scale. 
Without municipal cooperation, loss of ES provision corresponds to the settlement expansion area of a municipality. In contrast ES losses are more evenly distributed over the different municipalities if they cooperate (Figure 4). More cooperation partners in the fast-growing municipalities increases allocation options and, as a consequence, growth is distributed more evenly in the simulation. Thus, cooperation enables municipalities with high population growth and ES under pressure to mitigate ES losses by transferring parts of their spatial growth to smaller municipalities. Biggest beneficiary of the cooperation among municipalities is the town Visp, which displays significantly lower losses of ES when cooperating with other municipalities. Without municipal cooperation, Visp shows the highest loss of ES supply in the case study area. As soon as other municipalities do cooperate (ltd coop), a reduction of ES losses for Visp and a distinctive increase in ES losses of nearby municipalities (Visperterminen, Eggerberg, Baltschieder) occurs. Increasing the amount of cooperation partners leads to a further reduction of ES losses for Visp, while ES losses in all other municipalities (except Eisten and Saas-Almagell) continue to increase in comparison to the reference situation. With full cooperation, however, losses per municipality are lower than with "ltd coop" and more evenly spread (Figure 4, dark bars).

The consideration of building zones "bz" and ES in the allocation of settlement parcels also has important impacts on ES provision. The error bars in Figure 4 show the range of model outcomes for the respective municipality for different cooperation states. While the overall picture for limited municipal cooperation (ltd coop) remains basically the same, full cooperation over the whole region now offers much larger variety in the outcomes. Visp still outsources its spatial growth, but error bars now indicate ES losses for the other municipalities that are as low or even lower than ES losses without any cooperation. Thus, municipal cooperation allows effective preservation of ES provision in areas under pressure, but at the cost of increased ES losses in more peripheral areas.

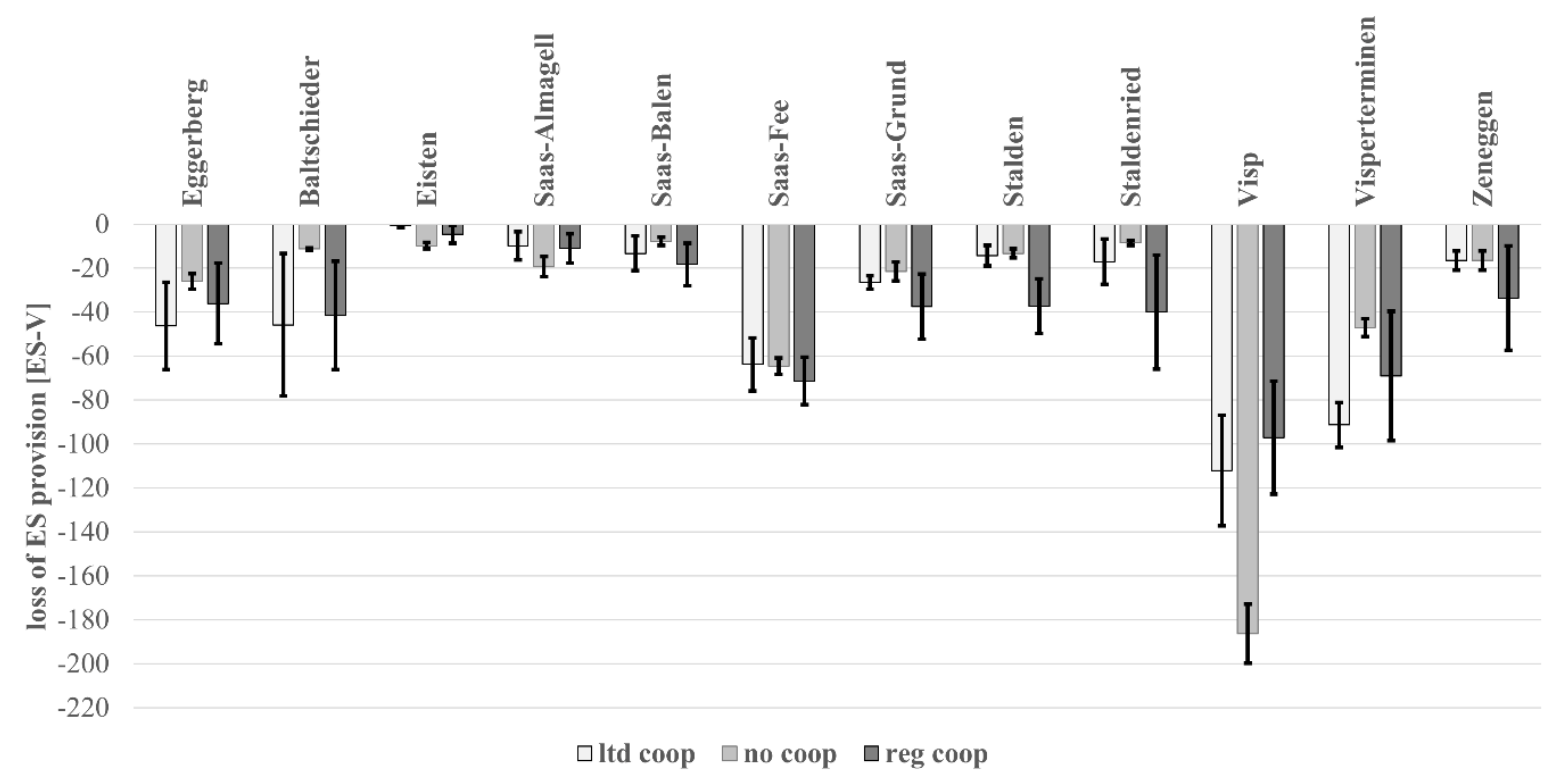

Figure 4: Average loss of ES provision per municipality, by cooperation levels. Error bars represent to what degree the spatial planning instruments "building zones" and "consideration of ES" affect ES losses.

In addition, the huge differences in ES losses between municipalities emphasize that regional level ES assessment is too coarse to effectively assess the ES trade-offs associated with different spatial planning instruments. 


\subsection{Impact of planning instruments on farm income}

Settlement growth reduces land for agricultural production and consequently affects agricultural production patterns and income. Thus, the extent of cooperation and the corresponding re-distribution of settlement areas also affect agricultural income (Figure 5). Results show full-time farmers reacting most sensitively to changes in cooperation levels, with their potential income gain or loss varying by up to \pm 6 percent. These farmers are located in the valley bottom and thus are highly affected by a re-allocation of settlement parcels around Visp. Part-time farmers with focus on breeding are subject to income changes as well, although less than full time farmers ( $\pm 4 \%$ income gain/loss compared to reference; Figure 5$)$. In contrast, the incomes of more eco-friendly farmers, traditional part-time farmers, and leisure farmers are less affected by the spatial planning instruments. Most farmers are better off when municipalities cooperate on a regional scale, although high variations of agricultural income even within the same farm type are high. Part-time eco-stewards are an exception to this. These farmers do not profit from cooperation at all, their loss of income increases with the level of cooperation since they are located in more peripheral municipalities. In summary, model results show that spatial planning creates winners and losers in the agricultural sector depending on the design of the instrument.

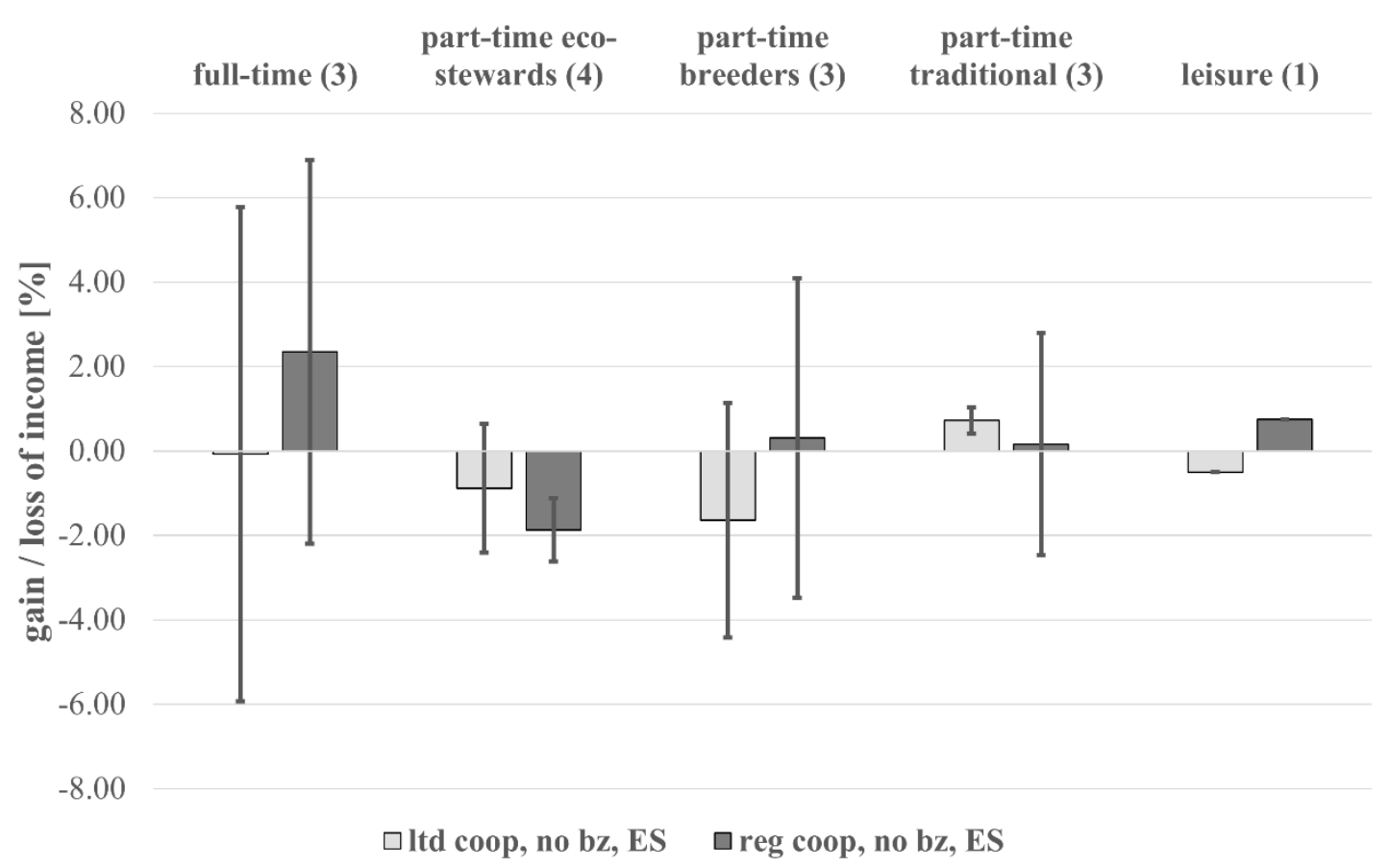

Figure 5: Impact of cooperation on agricultural income compared to the reference state ( $x$-axis), differentiated by farm type. Each farm type stands for a number of farming agents (= number in brackets) with different farm sizes and different amount of land available to them but sharing a similar approach to farming. Error bars indicate how agricultural income may vary between farming agents of the same type. See Appendix A.6 for more information on agricultural agents.

\subsection{Effect of spatial planning instruments on municipality level}

Focusing on changes in the municipality Visp (

Figure 6), we illustrate the trade-offs between ES in the same municipality under different spatial planning instruments. With respect to the provision of high quality ES, our simulation results imply a trade-off between increasing aesthetics and recreational values at the cost of a decrease in habitat provision. The impact on 
aesthetics is specifically high since overall availability is low, and many raster cells with high quality can be preserved compared to the reference state. This is expressed with a high impact ratio of 0.99, i.e., each preserved raster cell equals a one-point increase in the score for aesthetics ES value. In contrast, under the consideration of ES in spatial planning, more raster cells with low scores for water supply and habitat are sealed. Since such raster cells are not scarce, their impact ratio is low. For instance, Visp loses 10 high ES values of "habitat function" with an impact ratio of 0.15 , meaning it takes roughly seven raster cells for a one-point increase of the score for habitat ES value. This trade-off between different high quality ES allows to preserve 16 and 24 high quality ES values of "aesthetics" and "recreation (close-by)", respectively. Thus, model results imply that ubiquitously available low quality ES are traded-off for the preservation of more scarce high quality ones, when spatial planning includes explicit consideration of ES and municipal cooperation. Expanding the scope to the municipalities adjacent to Visp (Eggerberg, Baltschieder, Visperterminen), results are similar. Areas containing mainly low quality ES are traded off for preserving areas providing high quality ES, with Visperterminen even managing to score consistently higher than the reference state. In consequence, these results suggest that knowledge about ES quality trade-offs on a municipal level is crucial for an informed assessment of municipal cooperation.

Although results for Visp in Figure 4 show a clear improvement in ES preservation with municipal cooperation applied, adding the information on ES quality and impact ratio allows to better assess results with respect to their relative importance, i.e., which ES qualities have been preserved, and how much reserve of the respective ES qualities is available. 

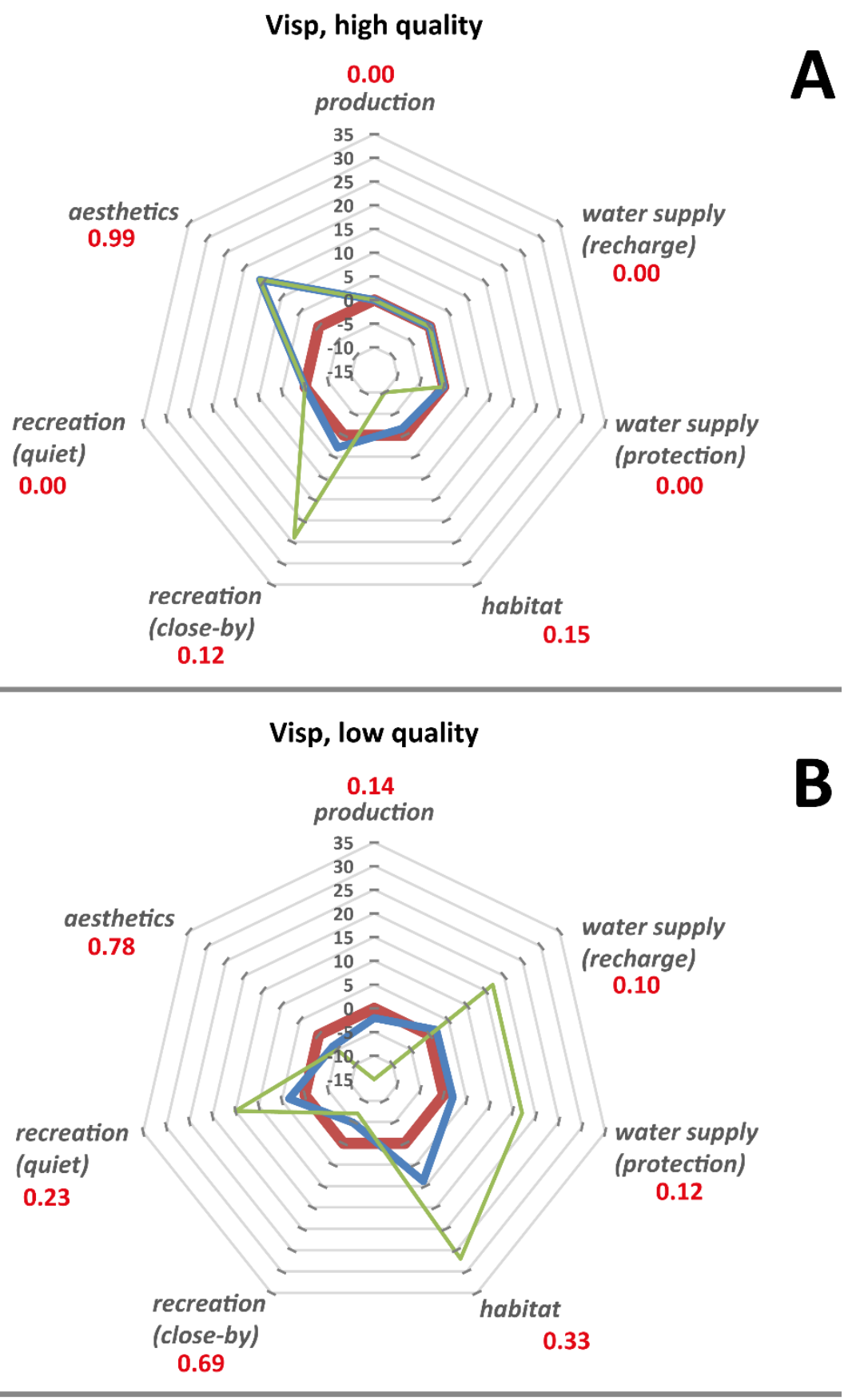

\section{Visp noBZ ES reg [\%] Visp noBZ ES reg [ES-V]}

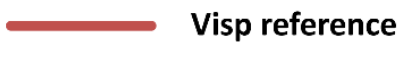

Figure 6: Trade-offs of different ES and across different qualities in the exemplary municipality V isp, V alais, regional cooperation assumed. Red lines = reference state; green lines = difference between reference state and ES-focused spatial planning; blue lines $=$ percentaged loss of ES quality in relation to maximum available ES value in municipality; impact ratio $=$ expresses scarcity of ES quality, with higher numbers meaning high scarcity, low number ubiquitous availability. 


\section{Discussion}

Comprehensive modelling approaches that link settlement growth and agro-economic land allocation with the provision of ES allow to quantify the effect of spatial planning instruments on bundles of ES across different scales. Such integrated, spatially explicit assessments across scales are called for by various authors in the ES literature (de Groot et al. 2010, Koschke et al. 2012).

Our results show that without any additional management or policy measures, ES provision will continue to decline in our case study region. A decline of ES provision in mountain regions under a trend situation is in line with many other studies addressing future ES provision in European mountain regions (Schröter et al. 2005; Grêt-Regamey, Walz, and Bebi 2008; Grêt-Regamey, Brunner, and Kienast 2012; Huber, Rigling, et al. 2013; Lundstrom et al. 2007). In addition to these studies, our results show particularly how settlement growth shares a large responsibility for these losses, in line with the findings of Price et al. (2015). The consideration of ES in the allocation of new settlement areas and the cooperation between municipalities to balance the spatially explicit impacts of new building zones significantly improve the preservation of areas providing bundles of scarce ES. This finding is supported by other interdisciplinary studies that identify coordination across different scales as key instrument in managing ES provision (Gret-Regamey et al. 2014; Hodder et al. 2014).

Moreover, our simulation results show the mismatches between scarce local ES provision and the large availability of certain ES in the case study area, which are often overlooked in ES assessment (Geijzendorffer, Martín-López, and Roche 2015). More importantly, our simulation results also imply that allocating settlement without considering ES and consideration of cooperation might create unintentional trade-offs. We could show that municipal cooperation allows effective preservation of ES provision in areas under pressure, but at the possibly high and uncertain trade-off of increased ES losses in more peripheral areas. Existing research implies that the identification of such trade-offs in ES provision is key in managing settlement growth (Geneletti 2011; Zank et al. 2016). In this context, stakeholders play a crucial role (Hein et al. 2006; Cavender-Bares et al. 2015; Kaye-Zwiebel and King 2014; Brooks et al. 2014; Gos and Lavorel 2012; Paletto et al. 2014). The integration of our modeling framework in a decision support platform allows to consider stakeholder preferences in the weighting of location factors and ES. This is an important step towards effective support of spatial planning processes (Dematteis 2009).

Testing the decision support platform in a first workshop (Figure 7), core stakeholders found the decision support platform to be an informative and valuable tool that encourages discussion on the spatial allocation of new settlement areas and the impact on ES. Of specific importance was the information on the spatially explicit results on ES quantities and qualities and their relative importance, i.e., which ES qualities have been preserved, and how much reserve of the respective ES qualities is available. Moreover, stakeholders emphasized the importance of distributional consequences of such spatial planning instruments on economic growth and income. 


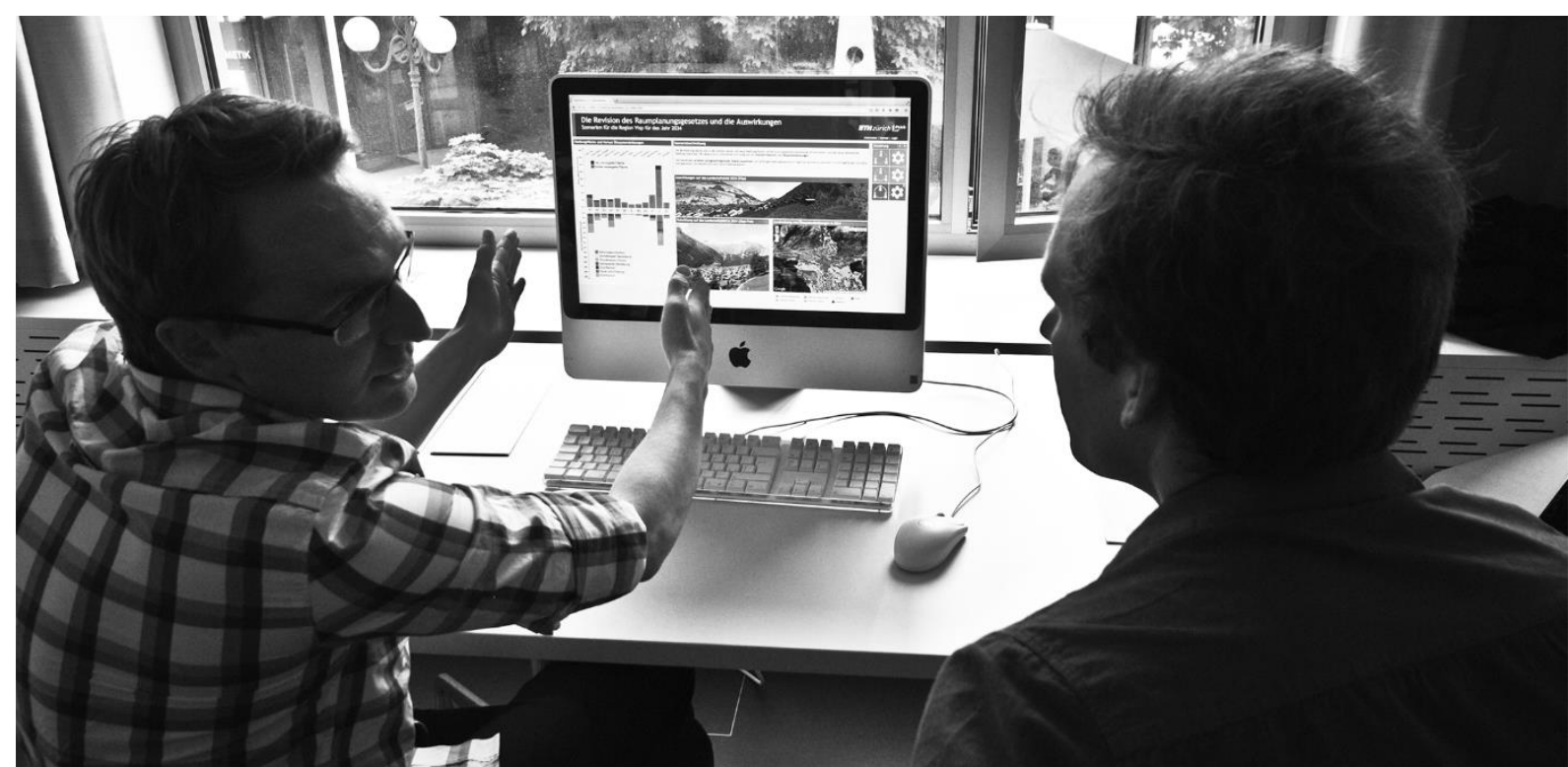

Figure 7: Testing the decision support platform in a first workshop with stakeholders. One of the authors explaining the platform (center) to a local stakeholder. Visp, V alais, Switzerland, May 2015.

In this context, the linkage of the two models allowed to take into account the effect of planning instruments on the income of different farming agents in the case study region, as well as explicitly providing the possibility to consider stakeholder preferences for different ES in the planning processes. Thus, our framework allows to uncover trade-offs in the agricultural sector and provides a basis for potential compensation measures which may help to effectively preserve ES. The knowledge about winners and losers of a new policy measure is key for the acceptance of spatial planning instruments (Wolsink 2007; Cowell, Bristow, and Munday 2011). Thus, our framework does not only quantify the effects of different spatial planning instruments on ES provision but also considers the scales at which (farming) decisions are made. This gives a new perspective on the close links between agriculture, preservation of ES and spatial planning, which is one of the reasons for the difficulty to develop effective spatial plans. Considering that Schirpke et al. (2012) pointed out that even changes in agricultural management can influence scenic beauty of landscape, these concerns might be justified even with seemingly low reductions of agricultural pay-off.

From a methodological perspective, the linkage of an agent-based, agro-economic optimization model with a cellular-automata-based settlement growth model showed that our framework is able to provide a better understanding of the land-use processes shaping mountainous landscapes and their impacts on ES provision. While we apply our framework to different spatial planning instruments, additional socio-economic and climate scenarios could be implemented to broaden the perspective for the stakeholders.

For the direct use in the design of zoning plans, the model would need to be spatially explicit on a parcel level instead of a raster cell level. However, such spatially explicit data is not available for the case study region. The framework, hence, is more suited for strategic assessment and a step towards integrating ES into spatial planning rather than a direct planning tool. The generalized land-use within raster cells is also a relevant point in view of current densification efforts in the case study region. In particular, the provision of ES could be different from the one we calculated, as green areas in urbanized environments can provide ES depending on the urban pattern and the design of the green areas (Tratalos et al. 2007; Kowarik 2011; Lundy and Wade 2011). Also, the framework assumes most of the ES to be static, despite the fact that ALUAM can model several ES dynamically. Such a static approach hinders exploring questions about ecological thresholds - a topic whose importance is increasingly acknowledged (Barnosky et al. 2012; Rockstrom et al. 2009). Moreover, it does not allow modelling of reduced ES provision due to increased fragmentation, caused directly or indirectly by settlement expansion. Finally, our approach assumes fixed housing style for simplification. While the framework 
can be adapted to the varying spatial demands of different housing styles, it cannot model how, for example, changes in housing density affect both, the provision of urban ES, and the quality of LFs (Smith, Clayden, and Dunnett 2009; Bramley and Power 2009; Coutts, Beringer, and Tapper 2010).

Still, we consider our framework to be a step in the right direction. We take a holistic approach, and look at the interactions of settlement growth, agricultural welfare, and ES provision. Our framework integrates trade-offs between ES, as well as between ES and agro-economic welfare under different spatial planning tools, across different scales as well as over time. Concurrently, it offers local stakeholders the option to review, comment, and prioritize results, thus embedding local knowledge into the decision-making process.

\section{Conclusion}

This contribution shows the ability of a new modelling framework to address the interactions between agriculture and settlement expansion and the role of spatial planning to secure ES provision. Taking into account ES provision and municipal cooperation in spatial planning would considerably modify the distribution of building zones and could improve the provision of ES in our case study region. Results clearly show the need for close, coordinated cross-sectoral cooperation in spatial planning to shape Swiss mountain cultural landscapes. In addition, our framework allows to assess ES trade-offs across different scales - an important step towards informed decision-making. Finally, the results identify winners and losers of specific planning instruments, a relevant information for real world spatial planning processes. The use of the simulation data in a decision support system demonstrates that the linkage of a recursive-dynamic agent-based land-use model and an automated settlement transition model offers additional, spatially explicit information to stakeholders on benefits, drawbacks, and consequences of different spatial planning instruments.

\section{Acknowledgments}

This work is part of the interdisciplinary National Research Program "NRP68 - Sustainable use of soil as a resource", funded by the Swiss National Science Foundation SNF. We are grateful to the MOUNTLAND project for the modelling support as well as to the many scientists and participants of the workshop held in Visp in May 2015. We would also like to thank two anonymous reviewers for their insightful comments, which greatly enhanced this article. Also, we want to thank Uta Fink for proof-reading this article for English. 


\section{Appendix}

\section{A.1. Detailed composition of municipal cooperations for "limited cooperation" scenario}

For the case study region, we assume four cooperations:

1) Saas-Fee, Saas-Balen, Saas-Grund, and Saas-Almagell (southern end of the valley): these municipalities are well-known tourist destinations and have successfully established themselves as "holiday region" already, including free public transport for tourists, a newspaper, a radio station and a shared homepage.

2) Visp, Visperterminen, Baltschieder, and Eggerberg (northern end of the valley):

Visp is the economic center of the case study area, with Visperterminen, Baltschieder, and Eggerberg within commuting distance.

3) Stalden, Staldenried and Eisten (central part of the case study area):

Stalden and Staldenried are connected to each other via cable-car. For the near future, a revision and upgrade is scheduled, requiring close cooperation of both municipalities. Eisten, a relatively small and remote village, geographically close and without any tourist attractions to speak of, is more likely to cooperate with the down-valley Stalden and Staldenried rather than the up-valley, tourist-oriented Saas-villages.

4) Zeneggen (western valley shoulder):

Small, remote village only accessible via a curvy mountain road. Not within easy commuting distance to Visp, especially in winter, nor close to any other municipality within the case study area. We assume this municipality to stay separate. 


\section{A.2. Calculation of settlement expansion rates and raster cell adjacency}

Settlement expansion rate is based on two values: permanent residents of a given municipality and the area of the municipality that is considered settlement. Each municipality within the case study area is processed separately. Data on permanent residents was drawn from the Swiss Federal Statistical Office FSO, using the municipal statistic from 1981 - 2010 (FSO 2012). Data on area considered settlement per municipality was drawn from Land Use Statistics, also provided by the Swiss Federal Statistical Office (FSO 2015a). Land Use Statistics differentiates 72 different land-use classes, with the first 36 classes being associated to settlement. These 36 classes also include roads, parks, graveyards, and the like. To calculate total settlement area per municipality, all 36 settlement classes have been considered. This decision was made based on two reasons: first, on a $100 \times 100$ m raster map, the content of a single raster cell within a settlement is rarely limited to one single land-use class, but in most cases also contains large, sealed areas. Second, upon expansion, a settlement will again require additional roads, parks, parking lots, etc. By including all 36 classes for calculation of settlement area, we take those needs into account even if they are not explicitly modeled. The municipal settlement area was then divided by the number of permanent residents in the respective years to get the average spatial demand per person. Spatial demand per person changes according to number of permanent residents and municipal settlement area until 2010. For the years from 2010 onwards, no more data on municipal settlement area is available. We therefore assume the spatial demand per person to remain unchanged. We also switch to Cantonal projections on the development of permanent residents for all municipalities after 2010 (FSO 2011), as there are no detailed population scenarios on municipal level available.

Finally, settlement area is calculated using average spatial demand per person multiplied by projected number of permanent residents. Number of required new settlement raster cells is:

$$
\begin{aligned}
& \text { equation } \left.A .1: A_{\text {new }}=\frac{\left(A_{\text {new }_{\text {tot }}}-A_{\text {old }}\right. \text { tot }}{}\right) \text {; } \\
& \text { with } A_{\text {new }}=\text { number of new settlement cells [ha]; } \\
& A_{\text {new }}=\text { total settlement area current year }[\mathrm{sqm}] ; \\
& A_{\text {old }_{\text {tot }}}=\text { total settlement area last year }[\mathrm{sqm}]
\end{aligned}
$$

For the calculation of raster cell adjacency, the original raster map (which is based on Land Use Statistics (FSO 2015a)) was first converted into a point file, where each point marks the center of the previous raster cell. Then, a buffer around each point was applied. Buffer radius was set to a distance that included all eight orthogonally and diagonally adjacent points. 


\section{A.3. Settlement distribution for the upper valley}
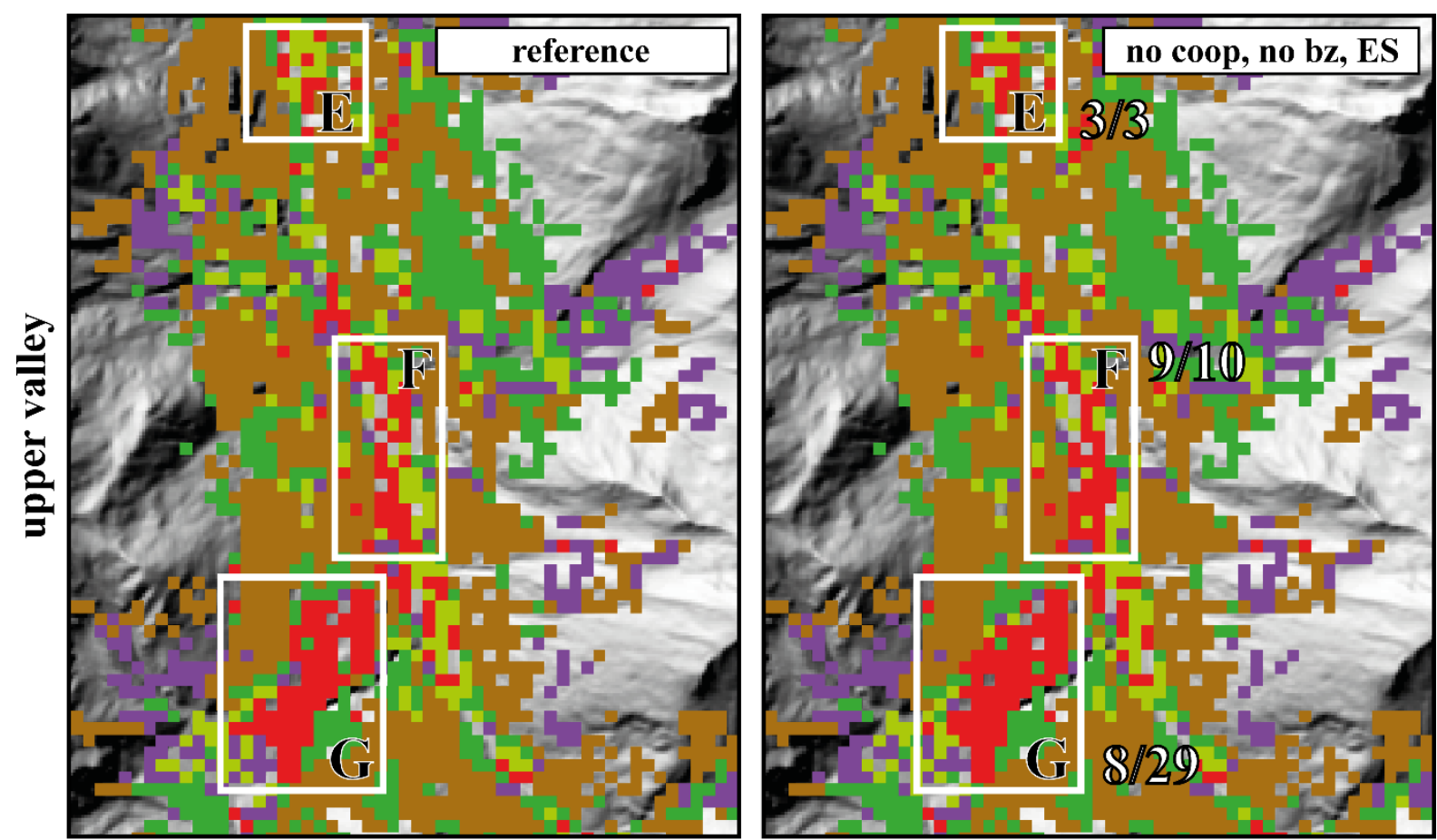

\section{Land use key}

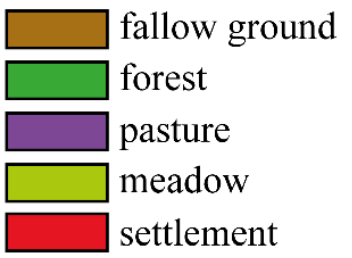

Whinite munmbers:

\# of new settlement cells that changed location / total \# of new settlement cells
Municipalities

E: Saas-Balen

F: Saas-Grund

G: Saas-Fee

Figure A. 1: Effect of both, ES consideration and removal of the building zones on settlement distribution in the upper valley. "no coop" = no cooperation among municipalities; "no bz" = building zones are not considered for settlement allocation; "ES" = ES are considered for settlement allocation.

Figure A. 1 shows how consideration of ES, as opposed to building zones, affects settlement distribution in the upper valley. Saas-Balen (E) and Saas-Grund display a very distinctive change, with 100\% and 90\% of new settlement raster cells being allocated differently upon consideration of ES. For Saas-Fee (G), the effect of ES consideration is less pronounced with $27.5 \%$. The most prominent reason for the striking difference is the restrictive topography in Saas-Fee, which limits settlement development to a relatively small area, likewise constraining options of DSA to allocate new settlement raster cells differently. 


\section{A.4. Detailed stakeholder affiliations}

The following list gives the details about the affiliation of the participating stakeholders. Each entry represents one (1) participant, for a total of ten participants.

Agricultural stakeholders:

- Local farmer

- Representative of Federal Office for Agriculture

- Representative of Agroscope, Agricultural Research Institution

- Member of chamber of agriculture Upper Valais

Cantonal stakeholders:

- Cantonal Office for Forest and Environmental Protection, Valais

- Cantonal Office for Spatial Development, Valais

- Cantonal Office for Structural Improvement, Valais

Non-Governmental Organisation (NGO) stakeholders:

- World Wildlife Fund WWF Valais

Administration stakeholders:

- Member of local municipal council

- Member of Cantonal Grand Council, Valais 


\section{A.5. DSA sensitivity}

For illustrating the sensitivity of DSA settlement allocation to different weight factors and different required numbers of adjacent settlement cells, we exemplarily use the base characteristics (initial area of settlement, spatial demand per person) of two municipalities within the case study region. We modify population growth to unrealistic levels for illustrative purposes and successively increase both, the weight of ES as well as the required number of adjacent settlement cells. We found the model to react very sensitively to changes in the number of required adjacent settlement cells, as was to be expected. For this contribution, we set a threshold of two cells. Table A. 1 shows the severe degradation of choices for a threshold of 3 cells and a significant path dependency if the threshold is set at 4 or higher. Figure A. 2 shows the resulting settlement pattern in a spatially explicit manner.

However, weighing is also an important factor, especially when a high number of adjacent settlement cells is required. Different allocation of a single cell can lead to a completely different settlement pattern due to path dependency effects (Table A. 1Error! Reference source not found.).

Table A. 1: Raster cells available for selection depending on number of required adjacent settlement cells.

\begin{tabular}{|c|c|c|c|c|c|c|}
\hline \multirow[b]{2}{*}{ Iteration } & \multicolumn{6}{|c|}{$\begin{array}{l}\text { amount of raster cells available for selection; } \\
\text { rac = required amount of (adjacent settlement) cells }\end{array}$} \\
\hline & 0 rac & $2 \mathrm{rac}$ & $3 \mathrm{rac}$ & $4 \mathrm{rac}$ & $5 \mathrm{rac}$ & $6 \mathrm{rac}$ \\
\hline 1 & 1614 & 142 & 43 & 9 & 9 & 9 \\
\hline 2 & 1611 & 146 & 44 & 11 & 10 & 10 \\
\hline 3 & 1608 & 147 & 45 & 10 & 11 & 11 \\
\hline 4 & 1608 & 147 & 45 & 10 & 11 & 11 \\
\hline 5 & 1602 & 147 & 42 & 5 & 7 & 7 \\
\hline 6 & 1597 & 151 & 43 & 6 & 4 & 4 \\
\hline 7 & 1589 & 148 & 39 & 2 & 38 & 38 \\
\hline 8 & 1583 & 152 & 42 & 5 & 3 & 3 \\
\hline 9 & 1574 & 149 & 38 & 1 & 40 & 40 \\
\hline 10 & 1561 & 145 & 37 & 37 & 39 & 39 \\
\hline 11 & 1546 & 160 & 35 & 35 & 35 & 35 \\
\hline 12 & 1529 & 161 & 35 & 37 & 38 & 38 \\
\hline 13 & 1518 & 181 & 45 & 2 & 3 & 3 \\
\hline 14 & 1510 & 192 & 49 & 55 & 2 & 2 \\
\hline 15 & 1502 & 198 & 51 & 55 & 3 & 3 \\
\hline 16 & 1496 & 196 & 56 & 58 & 3 & 3 \\
\hline 17 & 1491 & 202 & 59 & 1 & 58 & 58 \\
\hline 18 & 1486 & 207 & 60 & 62 & 58 & 58 \\
\hline 19 & 1481 & 211 & 61 & 1 & 58 & 58 \\
\hline 20 & 1476 & 213 & 63 & 2 & 59 & 59 \\
\hline 21 & 1471 & 219 & 62 & 2 & 61 & 61 \\
\hline 22 & 1466 & 222 & 63 & 62 & 1 & 1 \\
\hline 23 & 1461 & 224 & 62 & 1 & 62 & 62 \\
\hline 24 & 1457 & 231 & 65 & 64 & 2 & 2 \\
\hline 25 & 1453 & 233 & 68 & 64 & 62 & 62 \\
\hline 26 & 1449 & 231 & 67 & 65 & 64 & 64 \\
\hline 27 & 1446 & 233 & 69 & 67 & 1 & 1 \\
\hline 28 & 1443 & 237 & 68 & 68 & 65 & 65 \\
\hline 29 & 1440 & 240 & 69 & 68 & 66 & 66 \\
\hline 30 & 1437 & 240 & 71 & 1 & 67 & 67 \\
\hline 31 & 1435 & 246 & 71 & 71 & 2 & 2 \\
\hline 32 & 1433 & 248 & 73 & 1 & 68 & 68 \\
\hline 33 & 1431 & 249 & 74 & 71 & 69 & 69 \\
\hline 34 & 1430 & 250 & 76 & 2 & 1 & 1 \\
\hline 35 & 1429 & 251 & 77 & 1 & 1 & 1 \\
\hline 36 & 1428 & 251 & 76 & 74 & 72 & 72 \\
\hline 37 & 1427 & 250 & 77 & 75 & 1 & 1 \\
\hline 38 & 1426 & 250 & 78 & 1 & 72 & 72 \\
\hline
\end{tabular}




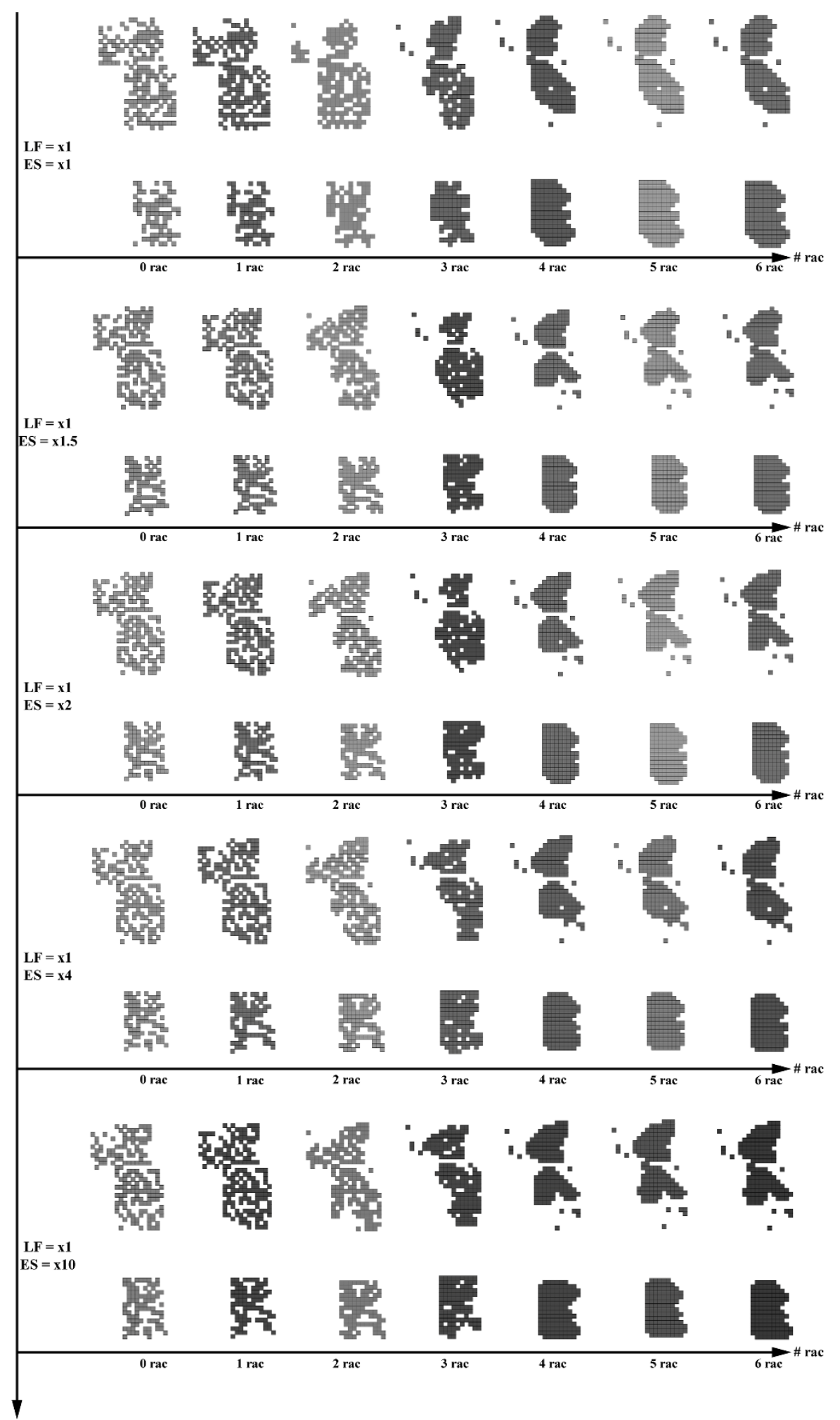

Figure A. 2: Sensitivity of the DSA model. The $x$-axis depicts the increasing number of required neighbors number of required adjacent cells, \# rac), the y-axis depict the increasing weight on ecosystem services. The same weight was always applied to all ecosystem services, individual weights have not been used. 


\section{A.6. Agricultural agents and their properties}

Farm types from Brändle et al. (2015)

\section{Type 1: Production-oriented farmers}

This type of farmer attaches great importance to generating an adequate income, high yields, and innovative products from their farming activities. They tend to be less involved in local traditions, breeding competitions, or providing ecosystem or landscape services. With a few exceptions, farming is their primary source of income and most or all available labor is devoted to farming.

\section{Type 2: Ecological and landscape stewards}

Farmers in this cluster place a stronger emphasis on the social, ecological, and landscape aspects of their farming activities than on the achievement of high yields or profits. They consider extensive land-use and the provision of ecological services to be both, an adequate source of income and an effective measure to increase biodiversity.

\section{Type 3: Part-time or leisure-oriented breeders}

Farmers in this cluster share a strong interest in being recognized as "good" farmers or breeders within their respective (farming) communities and to share their farming passion by participating in exhibitions, competitions, or cow fights. By engaging in these activities, they also aim to maintain local traditions and contribute to village life. They derive their main income off-farm.

\section{Type 4: Traditionalist leisure farmers}

Farmers of this type undertake small-scale farming as a way to maintain local traditions. Compared to type 3 , they do not aim for such a strong involvement in breeding, competitions, and local decision-making and perceive their opportunity costs to be much higher. All of these farmers are employed outside of agriculture and their farming activities depend strongly on off-farm work commitments and income.

\section{Type 5: Leisure-oriented farmers}

Farmers in this group place a high importance mainly on being involved in local decisions and village life. They are significantly less focused on achieving high income and yields than the other clusters but do not place a strong focus on ecological or competition objectives either. All of these farmers work outside of agriculture 
Table A. 2: Properties of agricultural agents in agro-economic optimization model ALUAM; taken from Brändle et al. (2014), Appendix, Table B2.

\begin{tabular}{|l|l|l|l|l|l|l|l|l|}
\hline $\begin{array}{l}\text { Agent } \\
\text { name }\end{array}$ & $\begin{array}{l}\text { Farm } \\
\text { type }\end{array}$ & $\begin{array}{l}\text { Opportunity } \\
\text { costs (of 10 } \\
\text { CHF) }\end{array}$ & $\begin{array}{l}\text { Available } \\
\text { work } \\
(2800 \\
\text { hours) }\end{array}$ & $\begin{array}{l}\text { Minimal } \\
\text { income } \\
\text { level } \\
\text { [CHF }]\end{array}$ & $\begin{array}{l}\text { Number } \\
\text { of farms }\end{array}$ & $\begin{array}{l}\text { Average } \\
\text { farm size } \\
\text { ha] }\end{array}$ & $\begin{array}{l}\text { thereof } \\
\text { slope } \\
18 \%\end{array}$ & $\begin{array}{l}\text { Land } \\
\text { per } \\
\text { agent } \\
\text { ha] }\end{array}$ \\
\hline MILAS & 1 & 0.2 & 1 & 25000 & 7 & 42.1 & 5.4 & 295 \\
\hline MASA & 1 & 0.2 & 0.6 & 25000 & 11 & 11.7 & 4.8 & 129 \\
\hline MUK & 1 & 0.5 & 0.6 & 25000 & 3 & 24.9 & 12.5 & 75 \\
\hline MIAA & 2 & 0.2 & 0.5 & 10000 & 44 & 5.2 & 2.8 & 227 \\
\hline MILA & 2 & 0.2 & 0.5 & 10000 & 10 & 13.1 & 6.1 & 131 \\
\hline MIAS & 2 & 0.2 & 0.8 & 10000 & 14 & 6.8 & 2.7 & 95 \\
\hline SCH & 2 & 0.2 & 0.5 & 0 & 23 & 7.1 & 4.0 & 164 \\
\hline MIAAS & 3 & 0.2 & 0.8 & 10000 & 6 & 15.6 & 8.3 & 93 \\
\hline AUR & 3 & 0.5 & 0.5 & 0 & 19 & 2.8 & 1.3 & 52 \\
\hline LEG & 3 & 0.5 & 0.5 & 0 & 18 & 6.6 & 2.5 & 119 \\
\hline MILS & 4 & 1 & 0.5 & 10000 & 4 & 26.1 & 11.0 & 104 \\
\hline MISCH & 4 & 1.25 & 0.3 & 0 & 26 & 6.4 & 3.0 & 165 \\
\hline AK & 4 & 1 & 0.3 & 10000 & 26 & 6.5 & 1.8 & 170 \\
\hline MIL & 5 & 0.2 & 0.3 & 0 & 40 & 4.0 & 2.4 & 162 \\
\hline
\end{tabular}

Table A. 3: Detailed key for farm type characteristics; taken from Brändle et al. (2014), Table 3, page 14.

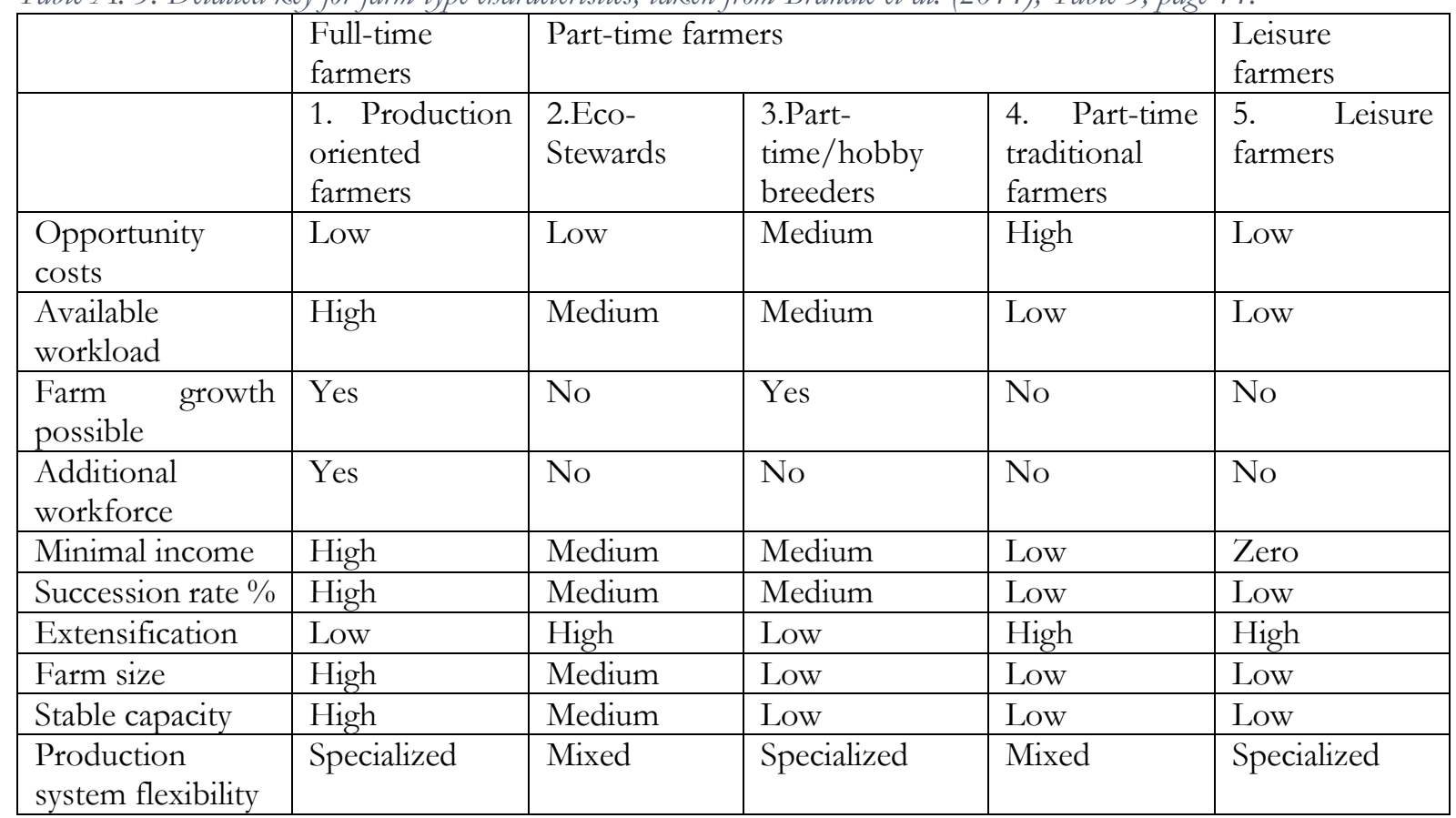




\section{A.7. Flowchart for DSA}

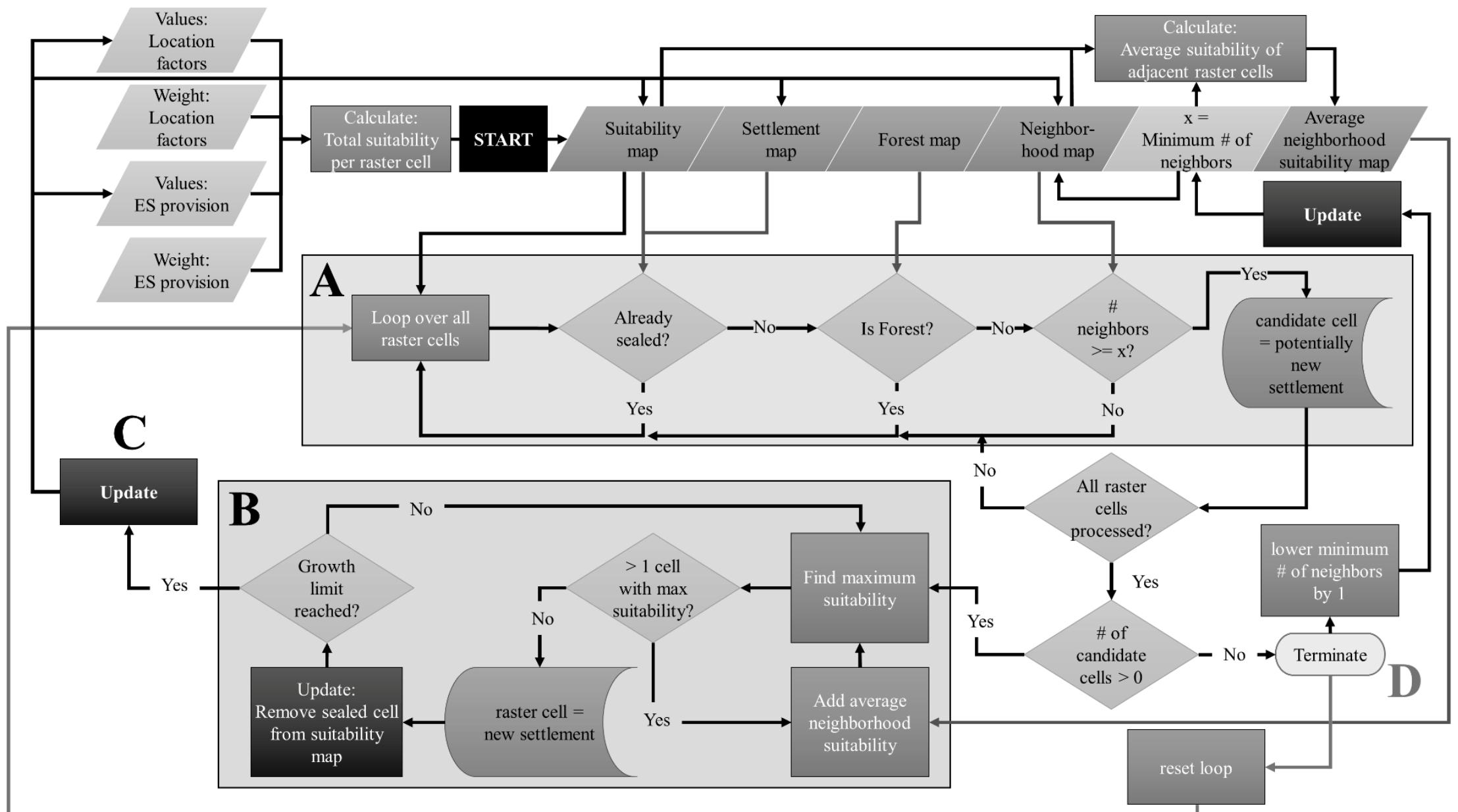

Figure A. 3: Basic flowchart for DSA. Black arrows mark regular processes, green arrows mark data input, blue arrows mark update processes, and yellow arrows mark termination/restart processes. Block $A$ contains the cellular automata, block B contains the rule-based algorithm. " $C$ " denotes update processes and dependencies. "D" denotes termination and fallback processes. 
The Dynamic Settlement Allocation Model DSA uses four stages to identify raster cells that are best suited for transition to settlement: a cellular-automata (CA) stage (marked "A"), a stage using a rule-based algorithm (marked "B"), an updating stage ("C"), and a termination/fallback-stage ("D").

Stage A processes the complete data set (i.e., every single raster cell available in the data set is included) and reduces the amount of transition candidates depending on the state of the cell itself as well as on the state and the number of its neighbors. For the sake of simplicity and readability, Figure A. 3 depicts the basic version of DSA, where only two states are considered: sealed (i.e., existing settlement) and forest. Forest is linked to the output of the agro-economic optimization model ALUAM. Consideration of further states is implemented for building zones and crop rotation areas. The CA can be expanded by additional states, which can also be linked to ALUAM if desired. Before stage B starts, CA double-checks that all raster cells have been processed.

After the CA has identified all candidate raster cells viable for transition to settlement, the rule-based algorithm in stage B employs a hierarchical selection process selecting the candidate raster cells with the highest suitability score for transition to settlement. Stage B iterates a number of times equal to the total number of settlement area in hectares to be allocated. Per iteration, one candidate raster cell is identified for transition to settlement. In case of tied suitability scores between two or more candidate raster cells, average suitability of unsealed raster cells in the respective neighborhoods is used as a tie-breaker.

Once stage B is finished and the selection of all candidate raster cells for transition to settlement is finalized, all data sets are updated. ES provision, LF quality, and previous affiliations of the raster cells with agricultural agents are deleted. Agricultural yields are set to zero. All agricultural managements and direct payments are blocked. The settlement map is updated. The neighborhood map is updated. All agricultural agents are updated.

Normally, DSA has sufficient amount of candidate raster cells available for the rule-based-algorithm (see Table A. 1). However, the number of candidate cells depends on the states considered by the CA, the overall size of the settlement, and the number of required adjacent cells (rac; see Appendix A.4). In case DSA runs into shortage of candidate cells, i.e., it needs to allocate more settlement area than there are candidate raster cells available, or if there are no candidate cells available at all, DSA terminates after stage A and lowers the rac threshold by one (1). The neighborhood map is updated and DSA restarts. In case of DSA still running into candidate raster cell shortage even after lowering the rac threshold to zero, the CA successively disables the queries of raster cell states one by one, starting with building zones. In theory, DSA could still get caught in an infinite loop if it encountered candidate raster cell shortage with rac threshold lowered to zero and all CA raster cell state queries disabled. However, it is a highly unlikely scenario. 


\section{References}

1. Antrop, MARC. 2005. "Why landscapes of the past are important for the future." Landscape and Urban Planning 70 (1-2):21-34. doi: 10.1016/j.landurbplan.2003.10.002.

2. Barnosky, A. D., E. A. Hadly, J. Bascompte, E. L. Berlow, J. H. Brown, M. Fortelius, W. M. GETZ, ET AL. 2012. "Approaching a state shift in Earth's biosphere." Nature 486 (7401):52-8. doi: $10.1038 /$ nature11018.

3. Bätzing, Werner, Manfred Perlik, And Majda DekLeVa. 1996. "Urbanization and Depopulation in the Alps." Mountain Research and Development 16 (4):335 - 50. doi: 10.2307/3673985

4. Beinat, EuRo. 1997. Value Functions for Environmental Management, Environment and Management Series: Springer.

5. Beniston, M. 2003. "Climatic change in mountain regions: A review of possible impacts." Climatic Change 59 (1-2):5-31. doi: Doi 10.1023/A:1024458411589.

6. Bramley, G., AND S. Power. 2009. "Urban form and social sustainability: the role of density and housing type." Environment and Planning B-Planning \& Design 36 (1):30-48. doi: 10.1068/b33129.

7. BRand, Fridolin Simon, Roman Seidl, Quang Bao Le, Julia Maria Brändle, and Roland WERnER SchOLz. 2013. "Constructing Consistent Multiscale Scenarios by Transdisciplinary Processes: the Case of Mountain Regions Facing Global Change." Ecology and Society 18 (2). doi: 10.5751/es-04972-180243.

8. Brändle, J. M., G. LangendiJK, S. Peter, S. H. Brunner, And R. Huber. 2014. "Sensitivity analysis of a land-use change model with and without agents to assess land abandonment and long-term re-forestation in a Swiss mounatin region." Land 3. doi: 10.3390/land30x000x.

9. Brändle, Julia, Simon Peter, Gaby LangendiJk, Sibyl H. Brunner, AND Robert Huber. 2015. "Sensitivity analysis of a land-use change model with and without agents to assess land abandonment and long-term re-forestation in a Swiss mountain region." Land 4, 475-512; doi: $10.3390 /$ land 4020475 .

10. Briner, S, R Huber, C Elkin, ANd A Gret-Regamey. 2012 . "Assessing the impacts of economic and climate changes on land-use in mountain regions: a spatial dynamic modeling approach." Agr Ecosyst Environ 149 (2012):50 - 63.

11. BRiner, S., C. ELKIN, AND R. HUBER. 2013A. "Evaluating the relative impact of climate and economic changes on forest and agricultural ecosystem services in mountain regions." J Environ Manage 129:414-22. doi: 10.1016/j.jenvman.2013.07.018.

12. BRINER, SimON, CHÉ ELKIN, AND ROBERT HUBER. 2013B. "Evaluating the relative impact of climate and economic changes on forest and agricultural ecosystem services in mountain regions." Journal of Environmental Management 129 (0):414-22. doi: http://dx.doi.org/10.1016/j.jenvman.2013.07.018.

13. Briner, Simon, ChÉ Elkin, Robert Huber, and AdRienne Grêt-Regamey. 2012. "Assessing the impacts of economic and climate changes on land-use in mountain regions: A spatial dynamic modeling approach." Agriculture, Ecosystems \& Environment 149:50-63. doi: 10.1016/j.agee.2011.12.011.

14. Briner, Simon, Robert Huber, Peter Bebi, ChÉ Elkin, Dirk R. Schmatz, And AdRienne GrêtRegameY. 2013. "Trade-Offs between Ecosystem Services in a Mountain Region." Ecology and Society 18 (3). doi: 10.5751/es-05576-180335.

15. Brooks, Emma G. E., KeVIn G. Smith, Robert A. Holland, Guy M. Poppy, and Felix Eigenbrod. 2014. "Effects of methodology and stakeholder disaggregation on ecosystem service valuation." Ecology and Society 19 (3). doi: 10.5751/es-06811-190318.

16. Brunner, Sibyl hanna, Robert Huber, and Adrienne Grêt-Regamey. 2016. "A backcasting approach for matching regional ecosystem services supply and demand." Environmental Modelling \& Software 75:439-58. doi: 10.1016/j.envsoft.2015.10.018.

17. Bryan, Brett A., Christopher M. Raymond, neville D. Crossman, and darla hatton MACDONALD. 2010. "Targeting the management of ecosystem services based on social values: Where, what, and how?" Landscape and Urban Planning 97 (2):111-22. doi: 10.1016/j.landurbplan.2010.05.002.

18. Bürgi, Matthias, Janet Silbernagel, Jianguo Wu, and Felix Kienast. 2014 . "Linking ecosystem services with landscape history." Landscape Ecology 30 (1):11-20. doi: 10.1007/s10980-014-0102-3.

19. Bürgi, Matthias, angela Straub, Urs Gimmi, and Daniel Salzmann. 2009. "The recent landscape history of Limpach valley, Switzerland: considering three empirical hypotheses on 
driving forces of landscape change." Landscape Ecology 25 (2):287-97. doi: 10.1007/s10980-0099412-2.

20. Cavender-Bares, Jeannine, Patricia Balvanera, Elizabeth King, and Stephen Polasky. 2015. "Ecosystem service trade-offs across global contexts and scales." Ecology and Society 20 (1). doi: 10.5751/es-07137-200122.

21. cocca, Giampaolo, Enrico Sturaro, luigi Gallo, and Maurizio Ramanzin. 2012. "Is the abandonment of traditional livestock farming systems the main driver of mountain landscape change in Alpine areas?" Land Use Policy 29 (4):878-86. doi: 10.1016/j.landusepol.2012.01.005.

22. Coutts, Andrew, Jason Beringer, and Nigel Tapper. 2010. "Changing Urban Climate and CO2Emissions: Implications for the Development of Policies for Sustainable Cities." Urban Policy and Research 28 (1):27-47. doi: 10.1080/08111140903437716.

23. Cowell, Richard, Gill Bristow, and Max Munday. 2011. "Acceptance, acceptability and environmental justice: the role of community benefits in wind energy development." Journal of Environmental Planning and Management 54 (4):539-57. doi: 10.1080/09640568.2010.521047.

24. de Groot, R. S., R. Alkemade, L. Bratat, L. Hein, and L. Willemen. 2010. "Challenges in integrating the concept of ecosystem services and values in landscape planning, management and decision making." Ecological Complexity 7 (3):260-72. doi: 10.1016/j.ecocom.2009.10.006.

25. DematTeis, GiusepPe. 2009. "Polycentric urban regions in the Alpine space." Urban Research \& Practice 2 (1):18-35. doi: 10.1080/17535060902727017.

26. Dupras, Jérôme, and Mahbubul Alam. 2014. "Urban Sprawl and Ecosystem Services: A Half Century Perspective in the Montreal Area (Quebec, Canada)." Journal of Environmental Policy \& Planning 17 (2):180-200. doi: 10.1080/1523908x.2014.927755.

27. Eigenbrod, F., V. A. Bell, H. N. Davies, A. Heinemeyer, P. R. Armsworth, and K. J. Gaston. 2011 . "The impact of projected increases in urbanization on ecosystem services." Proc Biol Sci 278 (1722):3201-8. doi: 10.1098/rspb.2010.2754.

28. Flury, CHRistian, Robert Huber, AND ERICH TASSer. 2013A. "Future of Mountain Agriculture in the Alps." :105-26. doi: 10.1007/978-3-642-33584-6_8.

29. - 2013в. "Future of Mountain Agriculture in the Alps." In The Future of Mountain Agriculture, edited by Stefan Mann, 105-26. Springer Berlin Heidelberg.

30. FOA, Swiss Federal OfFice for Agriculture. 2013. "AGIS." Bundesamt für Landwirtschaft BLW, Bern.

31. FOEN. 2015. "SonBase - GIS Noise Database of Switzerland." Swiss Federal Office for the Environment, Accessed 06-30. http://www.bafu.admin.ch/publikationen/publikation/01037/index.html?lang=de\&lang=en.

32. - 2015. "Digital Groundwater Protection Areas." Swiss Federal Office for the Environment, Accessed 06-30. https://map.geo.admin.ch/.

33. - "REN (National ecological network)." Swiss Federal Office for the Environment. http://www.bafu.admin.ch/gis/02911/07403/index.html?lang=de.

34. - ". "Wildlife corridors." Swiss Federal Office for the Environment. http://www.bafu.admin.ch/gis/02911/07403/index.html?lang=de.

35. FSO. 2015. "Digital soil suitability map." Swiss Federal Statistical Office, Accessed 06-30. http://www.bfs.admin.ch/bfs/portal/de/index/dienstleistungen/geostat/datenbeschreibung/di gitale_bodeneignungskarte.html.

36. - 2015. "Business Census." Swiss Federal Statistical Office, Accessed 06-30. http://www.bfs.admin.ch/bfs/portal/de/index/dienstleistungen/geostat/datenbeschreibung/ei dgenoessische_betriebszaehlung2.html.

37. - 2015. "Land Use Statistics GEOSTAT." Swiss Federal Statistical Office, Accessed 06-30. http://www.bfs.admin.ch/bfs/portal/de/index/infothek/erhebungen_quellen/blank/blank/ar ealstatistik/01.html.

38. - 20 15. "Kantonale Bevölkerungsszenarien 2010 - 2035." Swiss Federal Statistical Office, Accessed 16.03.2015. https://www.pxweb.bfs.admin.ch/Selection.aspx?px_language $=$ de\&px_db=px-x0104020000_105\&px_tableid=px-x-0104020000_105\px-x-0104020000_105.px\&px_type=PX.

39. - 2015. "Gemeindestatistik, 1981 - 2010." Swiss Federal Statistical Office, Accessed 05-27-2015. https://www.pxweb.bfs.admin.ch/Selection.aspx?px_language=de\&px_db=px-x0102020000_102\&px_tableid=px-x-0102020000_102 \px-x-0102020000_102.px\&px_type=PX.

40. - 2015. "Arealstatistik Standard nach 72 Grundkategorien." Swiss Federal Statistical Office, Accessed 2015-05-28. 
http://www.bfs.admin.ch/bfs/portal/de/index/dienstleistungen/geostat/datenbeschreibung/ar ealstatistik_noas04.html.

41. _- 2015в. "Statistik Schweiz." Swiss Federal Statistical Office.

42. ——. "Szenarien zur Bevölkerungsentwicklung der Schweiz 2015 - 2045." Swiss Federal Statistical Office, Accessed 18.08.2015. http://www.bfs.admin.ch/bfs/portal/de/index/themen/01/22/publ.html?publicationID=6646

43. FSOD. 2015. "Public Transportation Quality Classes." Swiss Federal Office for Spatial Development Accessed 06-30. http://www.are.admin.ch/themen/verkehr/00256/04271/index.html?

44. FUHRER, J., P. SMITH, AND A. GOBIET. 2014. "Implications of climate change scenarios for agriculture in alpine regions--a case study in the Swiss Rhone catchment." Sci Total Environ 493:1232-41. doi: 10.1016/j.scitotenv.2013.06.038.

45. GeiJzendorffer, Ilse R., Berta Martín-López, and Philip K. Roche. 2015. "Improving the identification of mismatches in ecosystem services assessments." Ecological Indicators 52:320-31. doi: 10.1016/j.ecolind.2014.12.016.

46. Geneletti, DAvide. 2011. "Reasons and options for integrating ecosystem services in strategic environmental assessment of spatial planning." International Journal of Biodiversity Science, Ecosystem Services \& Management 7 (3):143-9. doi: 10.1080/21513732.2011.617711.

47. Gibon, Annick, David Sheeren, Claude Monteil, Sylvie Ladet, and Gérard Balent. 2010. "Modelling and simulating change in reforesting mountain landscapes using a social-ecological framework." Landscape Ecology 25 (2):267-85. doi: 10.1007/s10980-009-9438-5.

48. Gos, PierRE, AND SANDRA LAVOREL. 2012. "Stakeholders' expectations on ecosystem services affect the assessment of ecosystem services hotspots and their congruence with biodiversity." International Journal of Biodiversity Science, Ecosystem Services \& Management 8 (1-2):93-106. doi: 10.1080/21513732.2011.646303.

49. Gret-Regamey, A., B. Weibel, K. J. Bagstad, M. Ferrari, D. Geneletti, H. Klug, U. Schirpke, AND U. TAPPEINER. 2014. "On the effects of scale for ecosystem services mapping." PLoS One 9 (12):e112601. doi: 10.1371/journal.pone.0112601.

50. Grêt-Regamey, Adrienne, Peter Bebi, IAN D. Bishop, And Willy A. Schmid. 2008. "Linking GISbased models to value ecosystem services in an Alpine region." Journal of Environmental Management 89 (3):197-208. doi: http://dx.doi.org/10.1016/j.jenvman.2007.05.019.

51. Grêt-Regamey, Adrienne, Sibyl hanna Brunner, and felix Kienast. 2012. "Mountain Ecosystem Services: Who Cares?" Mountain Research and Development 32 (S1):S23-S34. doi: 10.1659/mrd-journal-d-10-00115.s1.

52. Grêt-Regamey, AdRiEnNe, and Susanne KytZIA. 2007. "Integrating the valuation of ecosystem services into the Input-Output economics of an Alpine region." Ecological Economics 63 (4):786-98.

53. Grêt-Regamey, Adrienne, Ariane Walz, and Peter Bebi. 2008. "Valuing Ecosystem Services for Sustainable Landscape Planning in Alpine Regions." Mountain Research and Development 28 (2):15665. doi: $10.1659 /$ mrd.0951.

54. Hein, Lars, Kris van Koppen, Rudolf S. de Groot, and EkKo C. van IERland. 2006. "Spatial scales, stakeholders and the valuation of ecosystem services." Ecological Economics 57 (2):209-28. doi: 10.1016/j.ecolecon.2005.04.005.

55. Hodder, Kathy H., Adrian C. Newton, Elena Cantarello, and Lorretta Perrella. 2014. "Does landscape-scale conservation management enhance the provision of ecosystem services?" International Journal of Biodiversity Science, Ecosystem Services \& Management 10 (1):71-83. doi: $10.1080 / 21513732.2014 .883430$.

56. Huber, Robert, Simon Briner, Harald Bugmann, CHÉ Elkin, CHRistian HiRschi, Roman SeidL, RebeCCA SNelL, AND ANDREAS Rigling. 2014. "Inter- and transdisciplinary perspective on the integration of ecological processes into ecosystem services analysis in a mountain region." Ecological Processes 3 (1):9. doi: 10.1186/2192-1709-3-9.

57. Huber, Robert, harald Bugmann, Alexandre Buttler, and Andreas Rigling. 2013. "Sustainable Land-use Practices in European Mountain Regions under Global Change: an Integrated Research Approach." Ecology and Society 18 (3). doi: 10.5751/es-05375-180337.

58. Huber, Robert, Andreas Rigling, Peter Bebi, Fridolin Simon Brand, Simon Briner, Alexandre Buttler, Ché Elkin, et Al. 2013. "Sustainable Land Use in Mountain Regions Under Global Change: Synthesis Across Scales and Disciplines." Ecology and Society 18 (3). doi: 10.5751/es-05499-180336. 
59. Kaye-Zwiebel, Eva, and Elizabeth King. 2014. "Kenyan pastoralist societies in transition: varying perceptions of the value of ecosystem services." Ecology and Society 19 (3). doi: 10.5751/es-06753190317.

60. Kirchner, mathias, Johannes Schmidt, Georg Kindermann, Veronika Kulmer, Hermine MitTer, Franz Prettenthaler, Johannes Rüdisser, ET AL. 20 15. "Ecosystem services and economic development in Austrian agricultural landscapes — The impact of policy and climate change scenarios on trade-offs and synergies." Ecological Economics 109:161-74. doi: 10.1016/j.ecolecon.2014.11.005.

61. KoschKe, Lars, Christine Fürst, Susanne Frank, and Franz MaKeschin. 2012. "A multicriteria approach for an integrated land-cover-based assessment of ecosystem services provision to support landscape planning." Ecological Indicators 21:54-66. doi: 10.1016/j.ecolind.2011.12.010.

62. KowARIK, I. 2011 . "Novel urban ecosystems, biodiversity, and conservation." Environ Pollut 159 (89):1974-83. doi: 10.1016/j.envpol.2011.02.022.

63. Lienhard, Andreas, and TObias Binna. 2013. "Visibility Map, innovative GPU-Programmierung zur Sichtbarkeitsberechnung." In AGIT. Salzburg, Austria.

64. Lundstrom, C., S. Kytzia, A. Walz, A. Gret-Regamey, and P. Bebi. 2007. "Linking models of land use, resources, and economy to simulate the development of mountain regions (ALPSCAPE)." Environ Manage 40 (3):379-93. doi: 10.1007/s00267-005-0342-8.

65. Lundström, Corinne, Susanne Kytzia, Ariane Walz, Adrienne Gret-Regamey, and Peter BEBI. 2007. "Linking Models of Land Use, Resources, and Economy to Simulate the Development of Mountain Regions (ALPSCAPE)." Environmental Management 40 (3):379-93. doi: 10.1007/s00267-005-0342-8.

66. LUNDY, L., AND R. WADE. 2011 . "Integrating sciences to sustain urban ecosystem services." Progress in Physical Geography 35 (5):653-69. doi: 10.1177/0309133311422464.

67. Macdonald, D., J. R. Crabtree, G. Wiesinger, T. Dax, N. Stamou, P. Fleury, J. Gutierrez LAZPITA, AND A. GIBON. 2000. "Agricultural abandonment in mountain areas of Europe: Environmental consequences and policy response." J Environ Manage 59 (1):47-69. doi: 10.1006/jema.1999.0335.

68. MAlCZEWSKI, JACEK. 1999. GIS and Multicriteria Decision Analysis: John Wiley \& Sons.

69. - 2006. "GIS-based multicriteria decision analysis: a survey of the literature." International Journal of Geographical Information Science 20 (7):703-26. doi: 10.1080/13658810600661508.

70. Marini, Lorenzo, Paolo fontana, Sebastian Klimek, Andrea Battisti, and KeVin J. Gaston. 2009. "Impact of farm size and topography on plant and insect diversity of managed grasslands in the Alps." Biological Conservation 142 (2):394-403. doi: 10.1016/j.biocon.2008.10.034.

71. Marini, Lorenzo, SEBAstian KlimeK, AND Andrea Battisti. 2011 . "Mitigating the impacts of the decline of traditional farming on mountain landscapes and biodiversity: a case study in the European Alps." Environmental Science \& Policy 14 (3):258-67. doi: 10.1016/j.envsci.2010.12.003.

72. MEA, Millenium Ecosystem Assessment. 2005. Ecosystems and Human Well-Being: Synthesis. Washington D.C.: Island Press.

73. Messerli, P., T. Scheurer, AND H. Veit. 2011 A. "Between longing and flight - Migratory processes in mountain areas, particularly in the European Alps Context of contributions to this issue and outlook Foreword." Revue De Geographie Alpine-Journal of Alpine Research 99 (1-4):16-20.

74. Messerli, Paul, Thomas Scheurer, and Heinz Veit. 2011 B. "Between Longing and Flight Migratory processes in mountain areas, particularly in the European Alps." Revue de géographie alpine/Journal of Alpine Research 99-1 | 2011.

75. Monteiro, antonio T., francesco fava, Erika Hiltbrunner, Giampaolo Della Marianna, AND STEFANO BOCCHI. 2011 . "Assessment of land cover changes and spatial drivers behind loss of permanent meadows in the lowlands of Italian Alps." Landscape and Urban Planning 100 (3):28794. doi: 10.1016/j.landurbplan.2010.12.015.

76. Nelson, Erik, Gulllermo Mendoza, James Regetz, Stephen Polasky, heather Tallis, Drichard Cameron, Kai M. A. Chan, et al. 2009. "Modeling multiple ecosystem services, biodiversity conservation, commodity production, and tradeoffs at landscape scales." Frontiers in Ecology and the Environment 7 (1):4-11. doi: 10.1890/080023.

77. Nogués-Bravo, D., M. B. AraúJo, M. P. Errea, and J. P. Martínez-Rica. 2007. "Exposure of global mountain systems to climate warming during the 21st Century." Global Environmental Change 17 (3-4):420-8. doi: 10.1016/j.gloenvcha.2006.11.007. 
78. Okoli, Chitu, and Suzanne D. Pawlowski. 2004. "The Delphi method as a research tool: an example, design considerations and applications." Information \& Management 42 (1):15-29. doi: 10.1016/j.im.2003.11.002.

79. ORLAND, BARBARA. 2004. "Alpine milk: Dairy farming as a pre-modern strategy of land use." Environment and History 10 (3):327 - 64.

80. Paletto, A., G. Giacovelli, G. Grilli, J. Balest, and I. De MeO. 20 14. "Stakeholders' preferences and the assessment of forest ecosystem services: a comparative analysis in Italy." Journal of Forest Science 60 (22):472 - 83.

81. Perlik, M., P. Messerli, and W. Batzing. 2001. "Towns in the Alps: Urbanization processes, economic structure, and demarcation of European functional urban areas (EFUAs) in the Alps." Mountain Research and Development 21 (3):243-52. doi: Doi 10.1659/02764741(2001)021[0243:Tita]2.0.Co;2.

82. Perlik, Manfred, ANd Paul Messerli. 2004. "Urban Strategies and Regional Development in the Alps." Mountain Research and Development 24 (3):215 - 9. doi: 10.1659/0276-4741.

83. Powell, Catherine. 2003. "The Delphi technique: myths and realities." Journal of Advanced Nursing 41 (4):376-82. doi: 10.1046/j.1365-2648.2003.02537.x.

84. Price, Bronwyn, Felix Kienast, Irmi Seidl, Christian Ginzler, Peter H. Verburg, and Janine BOLLIGER. 2015. "Future landscapes of Switzerland: Risk areas for urbanisation and land abandonment." Applied Geography 57:32-41. doi: 10.1016/j.apgeog.2014.12.009.

85. Reed, M. S., A. Graves, N. Dandy, H. Posthumus, K. HubaceK, J. Morris, C. Prell, C. H. QuinN, AND L. C. STRINGER. 2009. "Who's in and why? A typology of stakeholder analysis methods for natural resource management." J Environ Manage $90 \quad$ (5):1933-49. doi: 10.1016/j.jenvman.2009.01.001.

86. Rockstrom, J., W. Steffien, K. Noone, A. Persson, F. S. Chapin, 3rd, E. F. Lambin, T. M. LENTON, ET AL. 2009. "A safe operating space for humanity." Nature 461 (7263):472-5. doi: $10.1038 / 461472 \mathrm{a}$.

87. Schirpke, UtA, Georg Leitinger, ERICH TASser, MARKus Schermer, MElanie Steinbacher, AND ULRIKE TAPPEINER. 2012. "Multiple ecosystem services of a changing Alpine landscape: past, present and future." International Journal of Biodiversity Science, Ecosystem Services \& Management:1-13. doi: 10.1080/21513732.2012.751936.

88. Schröter, Dagmar, Wolfgang Cramer, Rik Leemans, I. Colin Prentice, Miguel B. Arajo, Nigel W. Arnell, Alberte Bondeau, et Al. 2005. "Ecosystem Service Supply and Vulnerability to Global Change in Europe." Science 310 (5752):1333-7. doi: 10.1126/science.1115233.

89. Smith, Carl, Andy Clayden, and Nigel Dunnett. 2009. "An Exploration of the Effect of Housing Unit Density on Aspects of Residential Landscape Sustainability in England." Journal of Urban Design 14 (2):163-87. doi: 10.1080/13574800802670978.

90. Swisstopo, Federal Office of Topography. 2015. "Digital Elevation Model DHM25." Accessed 06-30. http://www.swisstopo.admin.ch/internet/swisstopo/de/home/products/height/dhm25.html.

91. - - 2015. "Topographic Landscape Model TLM." Accessed 06-30. http://www.swisstopo.admin.ch/internet/swisstopo/en/home/topics/geodata/TLM.html.

92. —. 2016. "swissBOUNDARIES3D / VECTOR200 Administrative Boundaries." Federal Administration, Accessed 2016-03-17. http://www.toposhop.admin.ch/en/shop/products/landscape/swissBoundaries3D_1.

93. Tratalos, Jamie, Richard A. Fuller, Philip H. Warren, Richard G. Davies, and Kevin J. GASTON. 2007. "Urban form, biodiversity potential and ecosystem services." Landscape and Urban Planning 83 (4):308-17. doi: 10.1016/j.landurbplan.2007.05.003.

94. Turoff, Harold A. Linstone; Murray. 1975. The Delphi Method: Techniques and Applications: Addison-Wesley Educational Publishers Inc.

95. VAZ, Domingos Martins, AND MARIA JoÃo MAtOS. 2014 . "Regional Polycentrism in a Mountainous Territory: The Case of Covilhã (Portugal) and Alpine Cities." European Planning Studies 23 (2):379. 97. doi: 10.1080/09654313.2013.865711.

96. VISP. 2015. "History of Visp." Municipality of Visp, Accessed April 8th. http://www.visp.ch/portraet/geschichtliches.php.

97. Viviroli, D., M. ZapPa, J. Gurtz, AND R. Weingartner. 2009. "An introduction to the hydrological modelling system PREVAH and its pre- and post-processing-tools." Environmental Modelling \& Software 24 (10):1209-22. doi: 10.1016/j.envsoft.2009.04.001. 
98. VSGIS. 2015. "Kantonales GIS des Kanton Wallis."

99. Walz, A., J. M. Braendle, D. J. Lang, F. Brand, S. Briner, C. Elkin, C. Hirschi, R. Huber, H. LISCHKE, AND D. R. SCHMATZ. 2014. "Experience from downscaling IPCC-SRES scenarios to specific national-level focus scenarios for ecosystem service management." Technological Forecasting and Social Change 86:21-32. doi: 10.1016/j.techfore.2013.08.014.

100. WOLSINK, MAARTEN. 2007. "Planning of renewables schemes: Deliberative and fair decision-making on landscape issues instead of reproachful accusations of non-cooperation." Energy Policy 35 (5):2692-704. doi: 10.1016/j.enpol.2006.12.002.

101. Zank, Ben, Kenneth J. Bagstad, Brian Voigt, and Ferdinando Villa. 2016. "Modeling the effects of urban expansion on natural capital stocks and ecosystem service flows: A case study in the Puget Sound, Washington, USA." Landscape and Urban Planning 149:31-42. doi: 10.1016/j.landurbplan.2016.01.004.

102. ZAPPA, MASSIMILIANO. 2002. "Multiple-response verification of a distirbuted hydrological model at different spatial scales." PhD Diss., Swiss Federal Institute of Technology ETH Zürich.

103. Zimmermann, PATRick, Erich TAsser, Georg Leitinger, and Ulrike Tappeiner. 2010. "Effects of land-use and land-cover pattern on landscape-scale biodiversity in the European Alps." Agriculture, Ecosystems \& Environment 139 (1-2):13-22. doi: 10.1016/j.agee.2010.06.010.

104. Zurich, CiTY OF. 2006. "Provision of Open Spaces for the City of Zurich." 